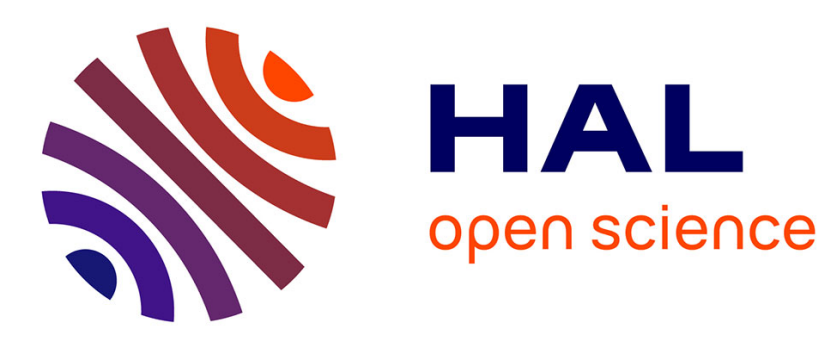

\title{
Remediation of soils contaminated by hydrophobic organic compounds: How to recover extracting agents from soil washing solutions?
}

Clément Trellu, Yoan Pechaud, Nihal Oturan, Emmanuel Mousset, Eric van Hullebusch, David Huguenot, Mehmet Oturan

\section{To cite this version:}

Clément Trellu, Yoan Pechaud, Nihal Oturan, Emmanuel Mousset, Eric van Hullebusch, et al.. Remediation of soils contaminated by hydrophobic organic compounds: How to recover extracting agents from soil washing solutions?. Journal of Hazardous Materials, 2021, 404, Part A, pp.124137. 10.1016/j.jhazmat.2020.124137 . hal-03168519

\section{HAL Id: hal-03168519 https://hal.science/hal-03168519}

Submitted on 18 Nov 2021

HAL is a multi-disciplinary open access archive for the deposit and dissemination of scientific research documents, whether they are published or not. The documents may come from teaching and research institutions in France or abroad, or from public or private research centers.
L'archive ouverte pluridisciplinaire HAL, est destinée au dépôt et à la diffusion de documents scientifiques de niveau recherche, publiés ou non, émanant des établissements d'enseignement et de recherche français ou étrangers, des laboratoires publics ou privés. 


\title{
Remediation of soils contaminated by hydrophobic organic
}

\section{compounds: How to recover extracting agents from soil}

\section{washing solutions?}

\author{
Clément Trellu ${ }^{1, *}$, Yoan Pechaud ${ }^{1}$, Nihal Oturan ${ }^{1}$, Emmanuel Mousset $^{2}$, Eric D. van \\ Hullebusch $^{1}$, David Huguenot ${ }^{1}$, Mehmet A. Oturan ${ }^{1,{ }^{*}}$ \\ ${ }^{1}$ Université Paris-Est, Laboratoire Géomatériaux et Environnement (EA 4508), UPEM, \\ 77454 Marne-la-Vallée, France. \\ ${ }^{2}$ Laboratoire Réactions et Génie des Procédés, Université de Lorraine, CNRS, LRGP, F- \\ 54000 Nancy, France
}

\section{Accepted in Journal of Hazardous Materials}

Corresponding authors Emails:

Mehmet.oturan@univ-eiffel.fr (Mehmet A. Oturan)

Clement.trellu@univ-eiffel.fr Clément Trellu) 


\section{Abbreviations}

2 AOP: advanced oxidation process; BDD: boron-doped diamond; CD: cyclodextrin; CMC:

3 critical micelle concentration; EA: extracting agent; EF: electro-Fenton; HPCD:

4 hydroxypropyl- $\beta$-cyclodextrin; HOC: hydrophobic organic compound; $\mathrm{K}_{\mathrm{CD}}$ : complex stability

5 (or equilibrium) constant between organic compounds and cyclodextrin; $\mathrm{K}_{\mathrm{m}}$ : micellar phase /

6 aqueous phase partition coefficient; MEUF: micellar-enhanced ultrafiltration process; NOM:

7 natural organic matter; PAH: polycyclic aromatic hydrocarbon; PHE: phenanthrene; SF soil

8 flushing; SW: soil washing; TX100: Triton X-100; TW80: Tween ${ }^{\circledR} 80$; VOC: volatile organic

9 compound.

\section{Abstract}

12 A lot of soil (particularly, former industrial and military sites) has been contaminated by various

13 highly toxic contaminants such as petroleum hydrocarbons, polycyclic aromatic hydrocarbons

14 (PAHs), polychlorobiphenyls (PCBs) or chlorinated solvents. Soil remediation is now required

15 for their promotion into new industrial or real estate activities. Therefore, the soil washing (SW)

16 process enhanced by the use of extracting agents (EAs) such as surfactants or cyclodextrins

17 (CDs) has been developed for the removal of hydrophobic organic compounds (HOCs) from

18 contaminated soils. The use of extracting agents allows improving the transfer of HOCs from

19 the soil-sorbed fraction to the washing solution. However, using large amount of extracting 20 agents is also a critical drawback for cost-effectiveness of the SW process. The aim of this

21 review is to examine how extracting agents might be recovered from SW solutions for reuse.

22 Various separation processes are able to recover large amounts of extracting agents according

23 to the physicochemical characteristics of target pollutants and extracting agents. However, an

24 additional treatment step is required for the degradation of recovered pollutants. SW solutions 
may also undergo degradation processes such as advanced oxidation processes (AOPs) with in situ production of oxidants. Partial recovery of extracting agents can be achieved according to operating conditions and reaction kinetics between organic compounds and oxidant species. The suitability of each process is discussed according to the various physicochemical characteristics of SW solutions. A particular attention is paid to the anodic oxidation process, which allows either a selective degradation of the target pollutants or a complete removal of the organic load depending on the operating conditions.

\section{$\underline{\text { Keywords }}$}

Soil washing; Reuse; Extracting agent; Separation; Degradation; Hydrophobic organic pollutant

Outline

I - Introduction: why should we try to recover extracting agents?

II - Separation processes

II. 1 - Air stripping and related technologies

II. 2 - Liquid - liquid extraction

II.3 - Membrane processes

II. 4 - Adsorption

III - Degradation processes

III.1 - Biological processes

6 III. 2 - Chemical, photochemical and electrochemical advanced oxidation processes

7 III.2.1 - Removal of target pollutants: generation of oxidant species and reaction mechanisms

III.2.2 - Effectiveness for the recovery of extracting agents 
III.3 - Soil washing solution reuse or total removal of the organic load? A focus on the possibilities offered by the anodic oxidation process

52 IV - Discussion

$53 \mathrm{~V}-$ Conclusions and Recommendations

54 Acknowledgements

55 References

56 


\section{I - Introduction: why should we try to recover extracting agents?}

The development of industrial activities led to the release into the environment of various hydrophobic organic compounds (HOCs) of environmental concern. Particularly, polycyclic aromatic hydrocarbons (PAHs), petroleum hydrocarbons, chlorinated solvents and polychlorobiphenyls (PCBs) are among the most widespread contaminants [1,2]. These pollutants have a severe toxic, carcinogenic and mutagenic potential to higher organisms, including humans [3]. Therefore, implementation of human activities at the vicinity of former industrial sites requires the development of sustainable remediation techniques. This is a major issue for both public authorities (healthcare risk management) and environmental engineering companies (development of environmental-friendly and cost-efficient soil remediation technologies). Conventional remediation techniques all present some major drawbacks such as low effectiveness (bioremediation in case of aged contaminated soils), high costs (thermal treatment or excavation) or selectivity towards target pollutants (e.g. volatile organic compounds (VOCs) for venting) $[1,4]$.

Soil is a porous and solid complex matrix made of a mixture of mineral particles and organic matter $[5,6]$. The presence of various carbonaceous phases in soils can also be associated to the specific history of each contaminated site and can lead to strong HOCs sequestration [7-10]. Using extracting agents (EAs) appeared to be a promising technique in order to improve the transfer of HOCs from the soil-sorbed fraction to the washing solution $[11,12]$. The pump and treat treatment technique enhanced by the use of extracting agents is named as soil flushing (SF). However, this in-situ technique is more difficult to implement and to control because of soil heterogeneities for several critical parameter such as permeability, porosity, nature and concentration of pollutants [13]. Therefore, a preliminary excavation step is often required. A step of granulometric separation is then carried out in order to perform the chemically enhanced soil washing (SW) process on the most contaminated fraction. Compared 
to SF, homogenization of the soil allows for optimizing the contact between extracting agents and soil pollutants. Thus, treatment efficacy is more easily monitored and the contact time is reduced during SW $[1,11]$.

A large range of extracting agents has been tested in the scientific literature. The use of synthetic surfactants above their critical micelle concentration (CMC) constitutes the most widespread technique $[12,14]$. The accumulation of HOCs in the SW solution originates from the reduction of the interfacial tension between non-aqueous phase liquid (NAPL) and aqueous phase as well as the increase of solubility due to partitioning of HOCs inside the hydrophobic space formed by micelles $[15,16]$. Synthetic surfactants are divided into four main categories, including anionic (e.g., sodium dodecylsufate $[17,18]$ ), cationic (e.g., quaternary ammonium derivatives [18]), amphoteric (e.g., cocamidoproyl hydroxysultaïne [19]) and non-ionic surfactants (e.g., Brij ${ }^{\circledR} 35$ [20,21], Tween ${ }^{\circledR} 80$ (TW80) [22-24], Triton ${ }^{\circledR}$ X 100 (TX100) [25]).

Surfactant solubilization of organic contaminants can be assessed by a micellar phase / aqueous phase partition coefficient $K_{m}$ (Eq. 1) [15]. The extraction capacity of extracting agents is not the only parameter to consider for selecting a suitable compound. In fact, some surfactants can have adverse effect on soil according to their chemical structure [26,27].

$$
K_{m}=\frac{X_{m}}{X_{a}}
$$

where $X_{m}$ and $X_{a}$ are the mole fraction of target pollutants in the micellar pseudo-phase and aqueous phase, respectively.

There is therefore an important challenge for chemical engineers to develop efficient, low-cost and eco-friendly surfactants. By comparison to synthetic surfactants, biosurfactants (from microbial origin) present several advantages such as high biodegradability, lower toxicity, ecological compatibility and the possibility to be produced in situ [28,29]. However, 
104 using biosurfactants at industrial scale is still impaired by high production cost and difficulties

105 to stimulate their in situ production at large scale [30,31]. Cyclodextrins (CDs) derivatives (with

106 higher solubility than native CDs) have also been tested as extracting agents $[11,32]$. They

107 allow increasing aqueous solubility of HOCs by forming inclusion complex according to their

108 respective complex stability (or equilibrium) constant $\left(\mathrm{K}_{\mathrm{CD}}\right)$ with organic compounds [11].

109 However, they are considered to be about ten times less effective than synthetic surfactants in

110 terms of pollutant removal from soil [11]. Other promising alternatives currently under

111 development include the use of gemini surfactant (made of two hydrophilic head groups and

112 two hydrophobic tails) $[14,33]$ and surfactant foams $[13,34]$.

113 Efficient removal of HOCs from soil by EA-enhanced SW depends on the nature of

114 target pollutants and soil characteristics $[11,12]$. This process results in the production of highly

115 concentrated effluents, containing target HOCs at toxic concentrations, natural organic matter

116 (NOM) from the soil as well as large amount of extracting agents [1]. Therefore, a suitable

117 strategy for disposal of the SW solution must be implemented [1]. The ecological footprint and

118 cost-efficiency of the whole process (i.e. soil excavation, SW, treatment of the SW solution,

119 Figure 1) depend strongly on both nature and amount of the surfactant consumed. As eco-

120 friendly surfactants are usually more expensive, the use of large amounts constitute a major

121 drawback for further full-scale application of this treatment strategy [1]. 


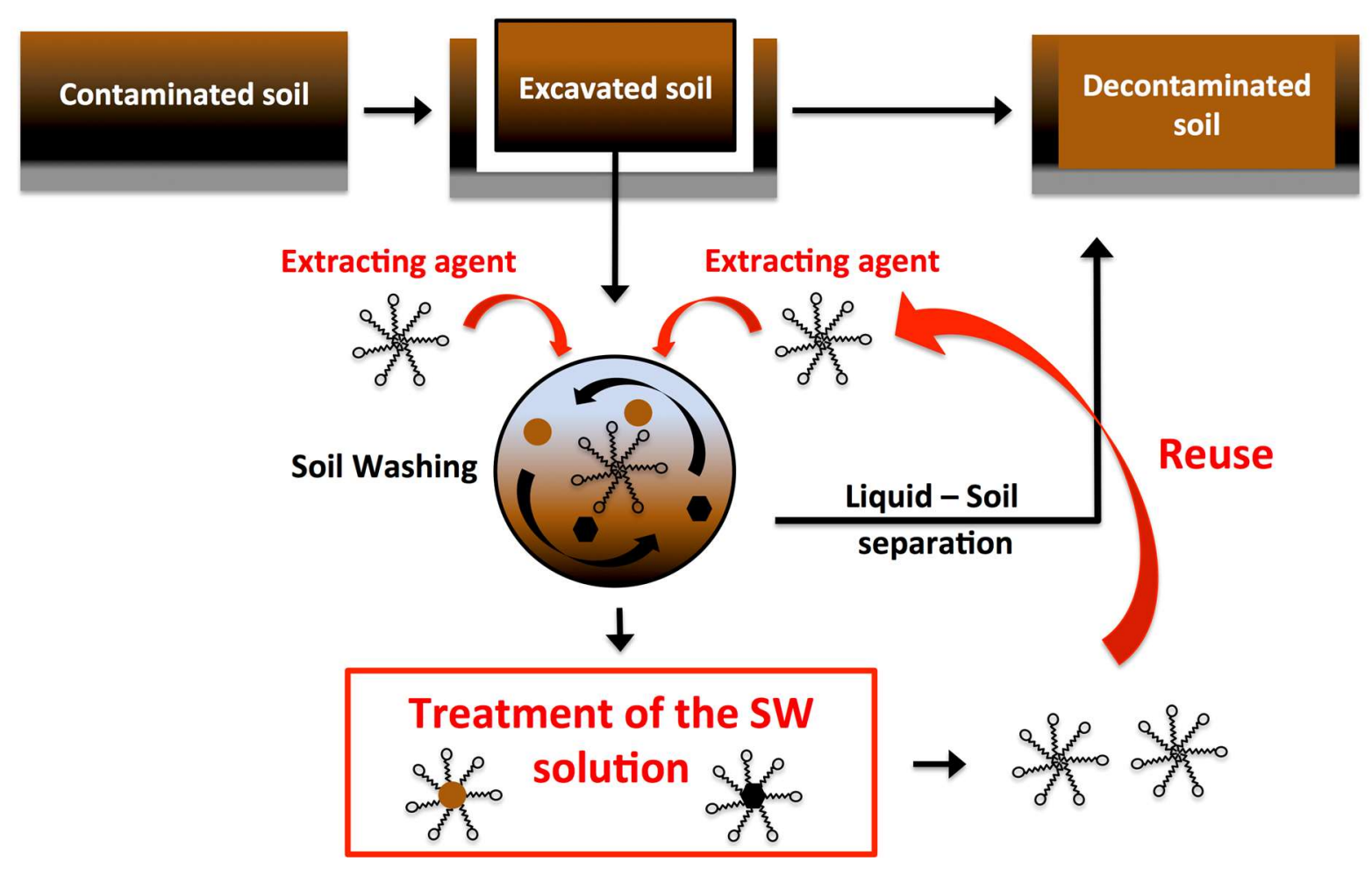

Figure 1- The different steps involved in the treatment of contaminated soils by integrated soil washing processes.

Optimizing the SW process is the most direct way to reduce the consumption of extracting agents. Decontamination of polluted soils by SW has already been widely reviewed in the literature by using either surfactants [14-16,24] or CDs [11] as extracting agents. The most important parameters to consider are: (i) the extraction effectiveness of the chosen EA, (ii) its cost, (iii) its soil sorption capacity (which can lead to important loss of extracting agent and adverse effects on soil quality) and (iv) the operating parameters, including concentration of EA, soil/liquid ratio, contact time, mixing conditions and number of successive washing steps [11]. Usually, optimal parameters are determined through preliminary tests. It is worth noting that the characteristics of the contaminated soil and pollutants have to be carefully investigated in order to assess the suitability of the SW process. According to the contamination history, soil pollution ageing and pollutant sequestration can strongly affect the availability of target pollutants for extracting agents [8,10,35-38]. Organic matter and clay content might also 
138 affect process effectiveness because of competitive solubilization of NOM, mobilization of

139 hardly settling particles or high adsorption of extracting agents on soil [15]. Finally, the

140 horizontal and vertical location of the contaminated soil has also to be carefully studied before

141 soil excavation. Excavation and treatment of non-polluted soil strongly increase the cost of the

142 process.

Once the SW has been optimized, it remains another way to further reduce the

144 consumption of extracting agents. Several research articles and one previous review paper

145 focused on the removal of the organic load from SW solutions [1]. However, a large amount of

146 extracting agents can be recovered by implementing a suitable treatment of the SW solution.

147 The objective is to improve the cost-efficiency and ecological footprint of soil remediation by

148 reusing the SW solution. However, it represents an additional treatment step requiring extra-

149 costs $[39,40]$. For this reason, this article aims at critically reviewing how to recover extracting

150 agents during the treatment of SW solutions, including separation and degradation processes.

151 Different processes are presented and their effectiveness for selective separation or degradation

152 of target pollutants is discussed according to the specific characteristics of SW solutions.

\section{II - Separation processes}

\section{II.1 - Air stripping and related technologies}

The SW process is usually not applied for the treatment of soil contaminated by VOCs

157 because of the important risk of accidental release. However, surfactant-enhanced SW can be 158 applied to soils contaminated with pollutants such as trichloroethylene, tetrachlorethylene or 159 perchloroethylene. In such case, air stripping and related technologies are relevant for the 160 removal of such compounds from SW solutions [41-44]. Air stripping is based on the formation 161 of a large air-water interfacial area in order to improve the mass transfer of semi-volatile 
compounds from the aqueous phase to the gas phase. Volatile or semi-volatile pollutants are

163 readily partitioned into the gas phase in contrast to non-volatile extracting agents. However,

164 gas injection in the presence of extracting agents can lead to significant foam formation [45]

165 which is considered as one of the main drawback of this process [46]. The use of hollow fiber

166 membranes instead of usual packed towers and tray air strippers can reduce these foaming

167 issues $[47,48]$. A lower formation of foam has also been observed with CDs compared to

168 synthetic surfactants. Air stripping was successfully performed at field-scale for recycling

169 hydroxypropyl- $\beta$-cyclodextrin (HPCD) for several successive SF steps $[32,49]$. Then,

170 contaminated air was treated through a granular activated carbon reactor.

Solubilization of target pollutants inside surfactant micelles or inclusion complex with

172 CDs has an important impact on the efficiency of the process. While the higher interfacial

173 resistance is often considered to only slightly decrease the global mass transfer [45,50],

174 extracting agents greatly reduce the molar fraction of free organic compounds in the aqueous

175 phase. Extracting agents act as a competing pseudo-phase for partitioning of the organic

176 contaminant in the gas phase [51,52]. This adverse effect increases with the hydrophobicity of

177 target pollutants, solubilization capacity of extracting agents (high $K_{m} / K_{C D}$ ) [45] and

178 concentration of extracting agent [44]. For example, tetrachlorethylene removal rate was 83, 61

179 and $37 \%$ when performing air stripping with hexadecyldisulfonate as extracting agent at 0,10

180 and $55 \mathrm{mM}$, respectively [45]. Thus, Lipe et al. (1996) have developed a surfactant air stripping

181 model (SASM) for assessing the efficiency of air stripping systems by taking into account the

182 effect of surfactants. It is based on the conventional non-equilibrium mass transfer model and

183 has been successfully validated by experiments at both bench and field scale $[45,48]$.

184 Vacuum processes have been investigated in order to improve the effectiveness of air

185 stripping [53]. Vacuum is used as the driving force for the transfer of target compounds from

186 the liquid to the gas phase. The surfactant stream can also be heated in order to increase the 
vapor pressure of contaminants. The two main advantages of this process are the higher separation effectiveness for contaminants with a lower volatility and the reduction of foaming issues [45].

Pervaporation has also been successfully applied to SW solutions [54] containing tetrachlorethylene [55], trichloroethylene [56], 1,1,1-trichloroethane [54,57] and toluene [57]. It is based on the vaporization of the SW solution through a selective non-porous polymeric membrane. Field demonstration and pilot-scale experiments demonstrated the high effectiveness of the process for the removal of these target compounds without affecting the performance of the recovered solution [55,57]. Different configurations can be used such as spiral wound modules [57] or hollow fiber membranes [56]. Similarly to previous processes, the use of high concentrations of extracting agents can decrease the performances in terms of selectivity and flux $[54,55]$.

\section{II.2 - Liquid - liquid extraction}

An organic liquid can be used as the partitioning phase for the extraction of target HOCs from SW solutions [44]. Liquid-liquid extraction is based on the mass transfer of target pollutants from the SW solution to the organic solvent. This process has been successfully applied at both bench and field scale for the removal of semi- and non-volatile organic compounds having high Henry's constants [58,59]. Using surfactants as EA, it has been reported a similar extraction capacity for the treated SW solution compared to the initial solution $[58,59]$. However, the process can be further complicated by emulsification of the solvent by the surfactant solution and solubilization of solvent molecules into the micellar pseudo-phase. Such phenomenon can be reduced by properly selecting the solvent, particularly by using highly hydrophobic solvents [58-60]. Hollow fiber membranes filled with the extracting solvent have also been used in order to eliminate emulsification and reduce the 
amount of solvent consumed [61]. Petitgirard et al. [62] developed different methods in order to reduce the amount of solvent used. It was based either on micro-emulsion or impregnation

214 of an organic membrane with oil. Lower amount of solvent allows decreasing the loss of 215 surfactant and facilitating the disposal of the contaminated solvent [44].

Hasegawa et al. [58] developed a model for liquid-liquid extraction in order to predict

217 the efficiency of this process for surfactant-containing solutions. The model depends on the 218 solvent / water partition coefficient $\left(K_{d}\right)$, micellar phase / aqueous phase partition coefficient $219\left(K_{m}\right)$, solvent-water ratio and hydrodynamic conditions (column height, retention time, water 220 velocity). Particularly, the partition of target pollutants in micelles $\left(K_{m}\right)$ is a crucial parameter. 221 The increase of the surfactant concentration significantly decreases the efficiency of the process 222 due to the micellar pseudo-phase acting as a competing partitioning phase [58]. Moreover, it 223 has been observed that the higher the hydrophobicity of target pollutants (high $K_{m}$ and $K_{C D}$ ), 224 the higher the adverse effects of extracting agents on removal efficiency is [58].

This process has also been applied to solutions containing CDs as extracting agents. For 226 example, liquid-liquid extraction with rapeseed oil was used for regeneration of a SF solution 227 containing methyl- $\beta$-cyclodextrin [62]. This lab-scale experiment allowed the regeneration of 228 the methyl- $\beta$-cyclodextrin solution for continuous SF. After two days of SF, almost complete 229 decontamination of the spiked sandy soil was achieved (96-98\% of PAH removal), pollutants were concentrated in the organic phase and the loss of methyl- $\beta$-cyclodextrin was negligible.

It is worth noting that liquid-liquid extraction leads to the production of highly

232 contaminated solvents, for which the disposal is a real challenge. Moreover, it also involves 233 high risks of handling (leaking storage tanks, exposure of workers via skin contact or inhalation).

234 Distillation systems have been applied for solvent/contaminant separation and reuse of the 235 solvent for further contaminant/EA separation steps [43], but such process represents an 236 important cost. 
The use of membrane technologies has also been investigated for the treatment of

240 SW/SF solutions. Most of the studies did not report selective surfactant-contaminant separation.

241 However, during SF, are often diluted in recovery wells by groundwater. Therefore, membrane

242 processes can also be used for re-concentration of the SF solution (e.g. after air stripping) before

243 reinjection into the contaminated zone [48]. For example, by using ultrafiltration membranes,

244 it was observed $93-99 \%$ of surfactant-contaminant retention from a SW solution containing

245 naphthalene and trichloroethylene as contaminants and linear alkyl diphenyloxide disulfonate

246 as surfactant [45]. The formation of micelles improves the retention of organic compounds [63].

247 Such micellar-enhanced ultrafiltration process (MEUF) is based on the formation of colloid-

248 sized surfactant micelles retained by the ultrafiltration membrane. Only one stud reported a

249 selective removal of target pollutants by ultrafiltration: $67 \%$ of the surfactant was recovered in

250 the permeate, while more than $90 \%$ of polychlorobiphenyls and $83 \%$ of oils were retained [64].

251 This result might be explained by the formation of oil droplets readily rejected by the membrane,

252 thus leading to a selective separation of surfactant monomers and pollutants.

\section{II.4 - Adsorption}

Adsorption is a widely used technology and has recently received great attention for the treatment of SW solutions because of promising results obtained for the recovery of extracting agents, especially with activated carbon $[1,65]$ (Table 1). Several studies have observed much higher removal rates of target pollutants than extracting agents because of the higher partition coefficient, higher hydrophobicity and lower concentration of target pollutants $[66,67]$.

260 Recently, the use of organo-bentonite and organo-layered double hydroxide has also been 261 investigated $[68,69]$. The objective of such material is to provide a strong affinity between target pollutants and the organic phase within bentonite or layered double hydroxide. Sorbent materials, pollutants and extracting agents already studied are reported in Table 1. 
265 in batch experiments by using the selectivity ratio $(S)$ (Eq. 4) [67]. Values reported in the

266 literature for synthetic SW solutions usually range between 5 and 100, according to operating 267 conditions (concentration/nature of EAs, target pollutant, sorbent material, dose, etc.). As 268 regards to the activated carbon dose in batch experiments, low amount (around $2 \mathrm{~g} \mathrm{~L}^{-1}$ ) was 269 reported to be sufficient to achieve $60 \%$ removal of $100 \mathrm{mg} \mathrm{L}^{-1}$ of PHE with a selectivity ratio 270 of 10 (initial concentration of TX100 was $5 \mathrm{~g} \mathrm{~L}^{-1}$ ) [67]. Much higher effectiveness was also 271 reached with lower PHE concentration [67]. However, selectivity ratio measured in synthetic 272 solutions cannot be used for prediction of the efficiency of the process with real SW solutions, 273 in which much more competition effects occur.

$$
S=\frac{C_{S M, j}}{C_{l, j}} \times \frac{C_{l, S A}}{C_{S M, S A}}
$$

274 where $C_{S M, j}$ is the concentration of the target pollutant sorbed onto the sorbent material ( $\mathrm{mg} \mathrm{g}^{-}$ $\left.275^{1}\right), C_{l, j}$ is the concentration of the target pollutant in the liquid phase $\left(\mathrm{mg} \mathrm{L}^{-1}\right), C_{l, S A}$ is the 276 concentration of extracting agent in the liquid phase $\left(\mathrm{g} \mathrm{L}^{-1}\right), C_{S M, S A}$ is the concentration of 277 extracting agent onto the sorbent material $\left(\mathrm{g} \mathrm{g}^{-1}\right)$ and $S$ is the selectivity ratio. By using a configuration with a continuous flow through column, such adsorption 279 process leads to a much shorter exhausting time of extracting agents compared to breakthrough 280 time of target pollutants [70].

282 Table 1 - Adsorption processes for the recovery of extracting agents - an overview of existing studies.

\begin{tabular}{ccccc}
\hline Sorbent & Pollutants & $\begin{array}{c}\text { Extracting } \\
\text { agents }\end{array}$ & Configuration References \\
\hline $\begin{array}{c}\text { Activated } \\
\text { carbon }\end{array}$ & $\mathrm{PHE}^{1}$ & $\mathrm{TX} 100^{2}$ & Batch & {$[66]$}
\end{tabular}




\begin{tabular}{|c|c|c|c|c|}
\hline $\begin{array}{l}\text { Activated } \\
\text { carbon }\end{array}$ & $\begin{array}{c}\mathrm{PHE}^{1}, \mathrm{FLUO}^{3}, \\
\mathrm{BaA}^{4}\end{array}$ & $\mathrm{TX} 100^{2}$ & Column & [70] \\
\hline $\begin{array}{l}\text { Activated } \\
\text { carbon }\end{array}$ & Trichloroethylene & $\mathrm{HPCD}^{5}$ & Batch & [71] \\
\hline $\begin{array}{l}\text { Activated } \\
\text { carbon }\end{array}$ & Mineral oil & RAMEB $^{6}$ & Column & [72] \\
\hline $\begin{array}{l}\text { Activated } \\
\text { carbon }\end{array}$ & $\mathrm{PHE}^{1}$ & $\begin{array}{l}\text { Mixture } \\
\text { SDS }^{7}- \\
\text { TX100² }\end{array}$ & Batch & [73] \\
\hline $\begin{array}{l}\text { Activated } \\
\text { carbon }\end{array}$ & $\mathrm{PHE}^{1}$ & $\mathrm{SDS}^{7}$ & Batch & [67] \\
\hline $\begin{array}{l}\text { Activated } \\
\text { carbon }\end{array}$ & $\mathrm{PHE}^{1}$ & $\mathrm{TX} 100^{2}$ & Column & [74] \\
\hline $\begin{array}{l}\text { Activated } \\
\text { carbon }\end{array}$ & FLUO $^{2}$ & $\mathrm{TX} 100^{2}$ & Batch & {$[75]$} \\
\hline $\begin{array}{l}\text { Activated } \\
\text { carbon }\end{array}$ & $\begin{array}{l}\text { Chlorinated } \\
\text { solvents }\end{array}$ & $\begin{array}{l}\mathrm{TX} 100^{2} \\
\mathrm{TX} 165^{8}\end{array}$ & Column & [76] \\
\hline $\begin{array}{l}\text { Activated } \\
\text { carbon }\end{array}$ & $\mathrm{PHE}^{1}$ & $\begin{array}{c}\text { TW409 } \\
{\text { TW } 80^{10}}, \\
\mathrm{~B}^{1} 0^{11}, \mathrm{~B} 35^{12}\end{array}$ & Batch & [77] \\
\hline $\begin{array}{l}\text { Organo- } \\
\text { bentonite }\end{array}$ & Various $\mathrm{PAH}^{13}$ & $\begin{array}{l}\text { TX114 } \\
\text { TX14, } \\
\text { TX } 305^{2}{ }^{15}\end{array}$ & Batch & [68] \\
\hline $\begin{array}{l}\text { Activated } \\
\text { carbon }\end{array}$ & Hexachlorobenzene & Rhamnolipid & Column & [78] \\
\hline $\begin{array}{l}\text { Activated } \\
\text { carbon }\end{array}$ & p-Cresol & TW80 $0^{10}$ & Batch & [79] \\
\hline Biochar & $\begin{array}{c}\mathrm{PHE}^{1}, \mathrm{FLUO}^{3}, \\
\mathrm{PYR}^{16}\end{array}$ & $\mathrm{TX} 100^{2}$ & Batch & [80] \\
\hline $\begin{array}{l}\text { Activated } \\
\text { carbon }\end{array}$ & $\mathrm{PHE}^{1}$ & TW80 ${ }^{10}$ & Batch & [81] \\
\hline $\begin{array}{l}\text { Activated } \\
\text { carbon }\end{array}$ & $\begin{array}{l}\text { Organochlorine } \\
\text { pesticide }\end{array}$ & $\mathrm{TX} 100^{2}$ & Batch & [82] \\
\hline $\begin{array}{l}\text { Macroporous } \\
\text { resin SP850 }\end{array}$ & $\mathrm{PHE}^{1}$ & $\begin{array}{l}\text { TX100² } \\
\text { SDBS }^{17}\end{array}$ & Batch & [83] \\
\hline $\begin{array}{l}\text { Organo- } \\
\text { LDH }^{18}\end{array}$ & $\mathrm{PHE}^{1}, \mathrm{PYR}^{16}$ & $\begin{array}{l}\mathrm{SDBS}^{17} \\
\mathrm{~B} 35^{12}\end{array}$ & Batch & [69] \\
\hline
\end{tabular}

$284{ }^{1}$ Phenanthrene; ${ }^{2,8,14,15}$ Triton X 100, 165, 114, 305; ${ }^{3}$ Fluoranthene; ${ }^{4}$ Benzo(a)anthracene; ${ }^{5}$ HPCD ${ }^{6}$ Randomly 285 methylated $\beta$-cyclodextrin; ${ }^{7}$ Sodium dodecylsulfate; ${ }^{9,10}$ Tween ${ }^{\circledR} 40,80 ;{ }^{11,12}$ Brij $^{\circledR} 30,35 ;{ }^{13}$ Polycyclic aromatic 286 hydrocarbon; ${ }^{16}$ Pyrene; ${ }^{17}$ Sodium dodecylbenzene sulfonate; ${ }^{18}$ Layered double hydroxides. 
The selectivity of adsorption processes tightly relies on the reduction of competition

289 phenomena for adsorption of target pollutants. Even if promising results have been obtained,

290 further investigations are necessary [71]. Particularly, it is required to better understand

291 competition mechanisms between partitioning of target pollutants inside micelles or inclusion

292 complex and adsorption on the sorbent material [71]. $K_{m}$ and $K_{C D}$ are important parameters to

293 take into consideration for the availability of pollutants for adsorption [84]. Besides, other

294 compounds from real SW solutions such as NOM could have strong adverse effects on the

295 selectivity ratio. For example, selectivity ratio was divided by 2 in a fluoranthene/TX100

296 mixture when adding $0.10 \mathrm{~g} \mathrm{~L}^{-1}$ of fulvic acids because these compounds participate to

297 additional pore blocking [75]. Besides, sand filtration is a required pre-treatment for real SW

298 solutions in order to prevent too much rapid fouling of the activated carbon filter by particulate

299 materials. The influence of the nature of EAs, target pollutants and sorbent materials (particle

300 size, pore size distribution, etc.) should also be further investigated. The extracting agent and

301 the sorbent material have to be carefully chosen in order to limit the phenomenon of pore

302 blocking, which can lead to a reduction of active sites available for target pollutant adsorption.

303 For example, it has been observed that the reduction of surface area of activated carbon after

304 TX100 adsorption was mainly ascribed to the adsorption on micropores [67]. Pore size

305 distribution could therefore be optimized in order to favour adsorption of target pollutants

306 instead of extracting agents.

307 The regeneration of sorbent materials is also a crucial issue for the sustainability of 308 adsorption processes. Thermal processes are currently widely used for activated carbon 309 regeneration. When performing thermal desorption, a large amount of energy is consumed and 310 a post-treatment of the contaminated gas stream is still required. Degradation of target 311 pollutants can be achieved by heating at high temperature under oxidizing conditions, but such 312 treatment usually reduce the potential for AC reuse because of a strong decrease of specific 
surface area and adsorption capacity $[85,86]$. Therefore, alternative regeneration processes are

314 currently investigated, such as biological treatments [87,88], microwave irradiation [70,89], ozone [86] or electro-Fenton (EF) processes [85,90,91]. The latter process seems to be a

316 promising technique based on the use of activated carbon as cathode, which allows for both 317 mineralization of organic pollutants and regeneration of the adsorption capacity of the spent 318 activated carbon [91].

\section{III - Degradation processes}

\section{III.1 - Biological processes}

Biological treatment (mainly aerobic processes) is one of the most popular processes in water treatment for the removal of biodegradable organic compounds. It is based on the consumption of organic compounds by a large range of microorganisms. Recent progress allows the application of this kind of treatment to various effluents in terms of nature and organic load. For a specific compound, removal rates and pathways depend on several physical, chemical and microbiological aspects [1]. Some organic compounds can be recalcitrant to biodegradation for different reasons such as the absence of microorganism able to use them as substrate, the presence of toxic concentrations of organic compounds or the lower bioavailability due to the physicochemical parameters of the environment [92]. Therefore, the development of an adapted biomass to a specific SW solution and the influence of extracting agents on the bioavailability of target pollutants are two key parameters [93-96].

As the uptake of organic compounds by microorganisms occur mainly via the aqueous phase, partition of HOC in the CD inclusion complex or in the surfactant micellar pseudo-phase can strongly influence biodegradation kinetics [97-99]. Different mechanisms are actually involved in the biodegradation of target pollutants in surfactant-containing solutions [92] 
337 (Figure 2). First, bacteria can directly utilize aqueous extra-micellar pollutants as substrate. 338 Then, pollutants diffusing from the micellar (or inclusion complex) to the aqueous phase 339 (kinetics in the range of microseconds to milliseconds) according to the micellar phase / 340 aqueous phase partition coefficient $\left(K_{m}\right)$ becomes also bioavailable. Biodegradation of 341 pollutants solubilized in micelles can also occur due to the formation of a hemi-micellar layer 342 around the bacteria cells (step I, Figure 2) and transfer of pollutants from the micellar phase to 343 this hemi-micellar layer (step II, Figure 2) [92]. However, these two steps might be kinetically 344 limiting for biodegradation [92].

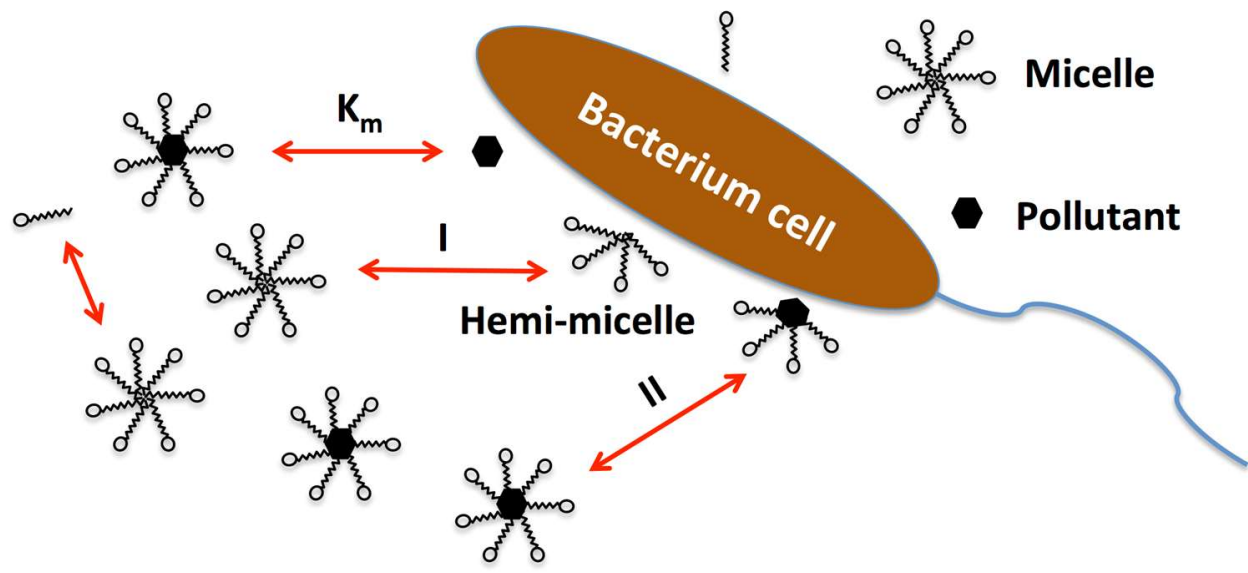

Figure 2 - Organic pollutant uptake by bacteria in soil washing solutions. $K_{m}$ is the micellar phase $/$ aqueous phase partition coefficient of the target pollutant. I: equilibrium between the hemi-micellar layer around the bacteria cells and micelles in the aqueous phase. II: equilibrium between pollutants

The complexity of such system often led to contradictory results [92]. On the one hand, 354 the enhancement of HOC biodegradation in solutions containing extracting agents has been mainly attributed to the increase of the solubility and bioavailability of HOCs $[94,95,100,101]$.

356 On the other hand, adverse effects have been often ascribed to the inhibition of the direct contact between microbial cells and target pollutants $[97,99,102]$, toxicity of extracting agents towards 
microorganisms [102-104] or preferential uptake of extracting agents as substrate

$359[103,105,106]$. Overall, the following trend is often observed the presence of low concentration

360 of extracting agent (below or close to the CMC for surfactants) enhances HOC biodegradation,

361 while bioavailability and biodegradability are reduced at high concentration of extracting agent

$362[92,96,98,99]$.

As extracting agents are usually used at high concentration during SW processes, it is very difficult to achieve a selective biodegradation of target pollutants in SW solutions because

of the protective environment formed by extracting agents. Therefore, only few authors have investigated SW solution recirculation after biological treatment. Navarro et al. [96] observed a selective biodegradation of PYR from a SW solution containing deoxyribonucleic acid (DNA) as extracting agent. The removal of PYR reached $99 \%$ after $1 \mathrm{~d}$, while more than $98 \%$ of deoxyribonucleic acid was recovered. This result was explained by the stability of DNA against the aerobic bacteria (Sphingomonas sp.) used in this study for degradation of PYR. Thus, the treated solution was re-used for four SW cycles with synthetic contaminated soil, with a high allow the reuse of a biologically-treated SW solution containing PHE and TW80 as extracting agent [107].

III.2.1 - Removal of target pollutants: generation of oxidant species and reaction mechanisms

Advanced oxidation processes (AOPs) have been largely studied for the treatment of 381 SW solutions. AOPs are well-known for the removal of recalcitrant organic pollutants [108]. 382 They are based on the in situ production of strong oxidants, mainly hydroxyl radicals, the 
second most powerful oxidizing agent known $\left(\mathrm{E}^{\circ}\left({ }^{\circ} \mathrm{OH} / \mathrm{H}_{2} \mathrm{O}\right)=2.8 \mathrm{~V} / \mathrm{SHE}\right)[109]$. Hydroxyl radicals are characterized by a very short lifetime (in the range of nanoseconds) and a nonselective feature towards organic compounds [110]. There are four main reaction pathways for the reaction of hydroxyl radical with organic compounds, including hydrogen atom abstraction (dehydrogenation), addition to an unsaturated bond (hydroxylation), ipso substitution (hydroxylation with release of halogen ion) and electron transfer (redox reactions) [110,111]. Aromatic compounds are the most reactive species with hydroxyl radicals since hydroxylation is typical for these kinds of compounds with rate constants in the range $10^{8}-10^{10} \mathrm{M}^{-1} \mathrm{~s}^{-1}$, while lower values are reported $\left(10^{6}-10^{8} \mathrm{M}^{-1} \mathrm{~s}^{-1}\right)$ for alkanes and alcohols for which reaction occurs through dehydrogenation [110]. Different methods are used for the production of hydroxyl radicals. Mainly photochemical, electrochemical, and Fenton-based processes have been applied to the treatment of SW solutions $[1,18,25,112-118]$.

Heterogeneous photocatalysis is based on photoactivation of a semiconductor (e.g. $\mathrm{TiO}_{2}$ ), leading to the production of an electron in the conduction band and a positive hole in the valence band $[119,120]$. These materials have a void energy region avoiding the recombination of electrons and holes. Thus, the reaction of electrons and positive holes with $\mathrm{O}_{2}, \mathrm{H}_{2} \mathrm{O}$, and $\mathrm{OH}^{-}$ leads to the production of oxidant species on the surface of the photocatalyst and in the bulk, including ${ }^{\bullet} \mathrm{OH}, \mathrm{H}_{2} \mathrm{O}_{2}, \mathrm{O}_{2}{ }^{\bullet-}[121]$.

The production of hydroxyl radicals during Fenton-based processes comes from the catalytic decomposition of hydrogen peroxide by ferrous iron $[108,110]$. The effectiveness of the process can be enhanced by using UV irradiation (photo-Fenton based processes) $[122,123]$, allowing a better regeneration of ferrous iron and the production of additional hydroxyl radicals from the photolysis of $\mathrm{Fe}(\mathrm{OH})^{2+}$ [124]. The development of iron-containing solids catalysts is also a promising way for reducing the production of iron sludge and allowing the application of the process at circumneutral $\mathrm{pH}[125,126]$. 

anodic oxidation by water discharge on the surface of anode with high oxygen evolution overpotential (such as boron-doped diamond, BDD) [127,128], (ii) EF process through in situ production of the Fenton's reagent [110]: $\mathrm{H}_{2} \mathrm{O}_{2}$ is produced from the two electron reduction of oxygen at a suitable cathode (such as gas diffusion or three-dimensional electrodes using 413 carbon-based porous materials combined with injection of compressed air in the solution), 414 while only a catalytic amount of ferrous iron is supplied and continuously regenerated by reduction of ferric iron at the cathode [129]. The EF process allows increasing the efficiency of the Fenton's process by avoiding the addition of chemical reagents, reducing waste reactions 417 and avoiding sludge formation [1,130]. Oxidation of inorganic anions in the solution $\left(\mathrm{SO}_{4}{ }^{2-}\right.$, $418 \mathrm{Cl}^{-}$, etc.) can also lead to the homogeneous production of oxidant species in the bulk such as 419 active chlorine, persulfate, sulphate radical, which also participate to the oxidation of organics 420 (“mediated oxidation”) [131,132].

Recently, a great attention has also been given to the development of AOPs based on 422 persulfate activation, due to several inherent advantages of sulphate radicals such as (i) the 423 convenience of storage and transportation of solid persulfate, (ii) the different way to activate 424 persulfate (e.g. thermal or electrochemical processes, $\mathrm{Fe}^{2+}$ ) and (iii) the longer lifetime of sulphate radicals compared to hydroxyl radicals [133-137].

427 is usually achieved when using such AOPs. Some examples of degradation kinetic rates are 428 reported in Table 2. When optimized operating conditions are used, the apparent degradation 429 kinetic rates of target pollutants in SW solutions are usually in the range $0.5-5 \mathrm{~h}^{-1}$. 


\begin{tabular}{|c|c|c|c|c|}
\hline Process & $\begin{array}{l}\text { Pollutants } \\
\text { (mM) }\end{array}$ & $\begin{array}{c}\text { Extracting } \\
\text { agent }(\mathbf{m M})\end{array}$ & $\begin{array}{c}\text { Maximum } \\
\text { degradation } \\
\text { kinetic rate }\left(h^{-1}\right)\end{array}$ & Reference \\
\hline $\begin{array}{l}\text { Photocatalysis } \\
\qquad\left(\mathrm{TiO}_{2}\right)\end{array}$ & $\mathrm{NAP}^{1}(0.03)$ & $\mathrm{B} 35^{2}(1.2)$ & 2.04 & [138] \\
\hline $\begin{array}{l}\text { Photocatalysis } \\
\qquad\left(\mathrm{TiO}_{2}\right)\end{array}$ & $\mathrm{PCP}^{3}(0.2)$ & $\begin{array}{l}\beta-\mathrm{CD}^{4}, \mathrm{MCD}^{5} \\
\mathrm{HPCD}^{6}(0-5)\end{array}$ & 5.3 & [139] \\
\hline $\begin{array}{c}\text { Solar- } \\
\text { Photocatalysis } \\
\left(\mathrm{TiO}_{2}\right)\end{array}$ & $\operatorname{NAP}^{1}(0.2)$ & $\begin{array}{c}\mathrm{TX} 100^{7}(0.04- \\
0.13)\end{array}$ & 4.2 & [140] \\
\hline $\begin{array}{l}\text { Photocatalysis } \\
\qquad\left(\mathrm{TiO}_{2}\right)\end{array}$ & $\begin{array}{l}\text { Aromatic } \\
\text { compounds }\end{array}$ & $\mathrm{B} 35^{2}(25)$ & $0.12-3.48$ & {$[141]$} \\
\hline $\begin{array}{l}\text { Photocatalysis } \\
\qquad\left(\mathrm{TiO}_{2}\right)\end{array}$ & $\mathrm{PCP}^{3}(0.018)$ & $\begin{array}{c}\mathrm{TX} 100^{7}(0.023- \\
1.01)\end{array}$ & 3.3 & [89] \\
\hline \multirow[t]{2}{*}{$\begin{array}{c}\text { Solar- } \\
\text { Photocatalysis } \\
\left(\mathrm{TiO}_{2}\right)\end{array}$} & Alkylphenols & $\begin{array}{c}\mathrm{B}^{3} 5^{2}, \mathrm{C}_{12} \mathrm{E}_{8} \\
\mathrm{SDS}^{8}, \text { mixtures } \\
\quad(1-15)\end{array}$ & 9.3 & {$[20]$} \\
\hline & & None (water) & 4.86 & \\
\hline \multirow[t]{2}{*}{ Photo-Fenton } & $\mathrm{TNT}^{9}(0.5)$ & & & [142] \\
\hline & & $\operatorname{MCD}^{5}(5)$ & 10.05 & \\
\hline \multirow[t]{2}{*}{$\mathrm{EF}$} & $\mathrm{PCP}^{3}(0.1)$ & $\operatorname{HPCD}^{6}(5)$ & 0.546 & {$[143]$} \\
\hline & & $\operatorname{HPCD}^{6}(8.8)$ & 1.56 & \\
\hline \multirow[t]{3}{*}{$\mathrm{EF}$} & $\operatorname{PHE}^{10}(0.1)$ & & & [144] \\
\hline & & TW80 ${ }^{11}(0.6)$ & 0.78 & \\
\hline & & $\operatorname{HPCD}^{6}(6)$ & $0.83-2.61$ & \\
\hline \multirow[t]{3}{*}{$\mathrm{EF}$} & PAHs & & & [145] \\
\hline & & TW80 $11(5.6)$ & $0.20-0.72$ & \\
\hline & $\operatorname{NAP}^{1}(0.83)$ & & 0.9 & \\
\hline \multirow[t]{2}{*}{$\begin{array}{l}\text { Anodic } \\
\text { oxidation }\end{array}$} & & $\mathrm{CAS}^{13}(9.1)$ & & [146] \\
\hline & PYR $^{12}(0.27)$ & & 0.66 & \\
\hline
\end{tabular}

$434 \quad{ }^{1}$ Naphthalene; ${ }^{2}$ Brij ${ }^{\circledR} 35 ;{ }^{3}$ Pentachlorophenol; ${ }^{4} \beta$-cyclodextrin; ${ }^{5}$ Methyl- $\beta$-cyclodextrin; ${ }^{6}$ Hydroxypropyl- $\beta$ -

435 cyclodextrin; ${ }^{7}$ Triton X 100; ${ }^{8}$ Sodium dodecylsulfate; ${ }^{9}$ Trinitrotoluene; ${ }^{10}$ Phenanthrene; ${ }^{11}$ Tween ${ }^{\circledR} 80 ;{ }^{12}$

436 Pyrene; ${ }^{13}$ Cocamidopropylhydroxysultaine 
The specificity of SW solutions requires giving a special attention for the understanding

439 of oxidation mechanisms, according to the process used, operating conditions, target pollutant

440 and extracting agent used. Target pollutant removal usually requires high energy and/or reagent

441 consumption, due to the high organic load of SW solutions. Concentrations of extracting agents

442 are usually in the range of $1-100 \mathrm{~g} \mathrm{~L}^{-1}[1,11]$. Moreover, a large amount of soil organic matter

443 is also mobilized in the SW solution [1]. Since hydroxyl radicals act in a non-selective way,

444 there is therefore a huge competition for oxidation [112,147-149] and wasting reactions from

445 hydroxyl radical scavengers strongly reduce the kinetics of target pollutant degradation. This

446 high oxidant demand is the main issue for the treatment of SW solution by AOPs. For example,

$44749 \mathrm{~g} \mathrm{~L}^{-1}$ (using sequential addition) and $30 \mathrm{~g} \mathrm{~L}^{-1}$ of $\mathrm{H}_{2} \mathrm{O}_{2}$ was necessary to achieve $95 \%$ and

$44896 \%$ COD removal from a SW solution $[25,146]$. As regards to the EF process, the treatment

449 of a SW solution containing PAH and TW80 as EA, required $0.69 \mathrm{kWh}$ per gram of TOC

450 removed [145].

Besides, solubilization of target pollutants inside surfactant micelles and inclusion complex with CDs reduces the effectiveness of oxidation processes by decreasing the availability of target pollutants towards oxidant species in the aqueous phase because of 454 formation of a protective environment [132,144,150,151]. However, different mechanisms occur when CDs are used as extracting agents during Fenton-based processes. The formation 456 of a ternary complex CD-pollutant-Fe ${ }^{2+}$ has been observed $[152,153]$. This phenomenon allows 457 improving the effectiveness of Fenton-based processes thanks to the production of hydroxyl 458 radicals close to target pollutants $[142,144,154]$.

As regards to anodic oxidation, hydroxyl radicals are only present in a thin layer (few $\mathrm{nm}$ ) on the anode surface. Therefore, reaction with organic compounds strongly depends on their mass transport from the bulk to the anode surface [128]. Formation of large size micelles 
463 [155]. However, production of oxidant species in the bulk through mediated oxidation

464 (favoured at high current density) can still participate in the degradation of micelles during 465 electro-oxidation of SW solutions [132] (Figure 3).

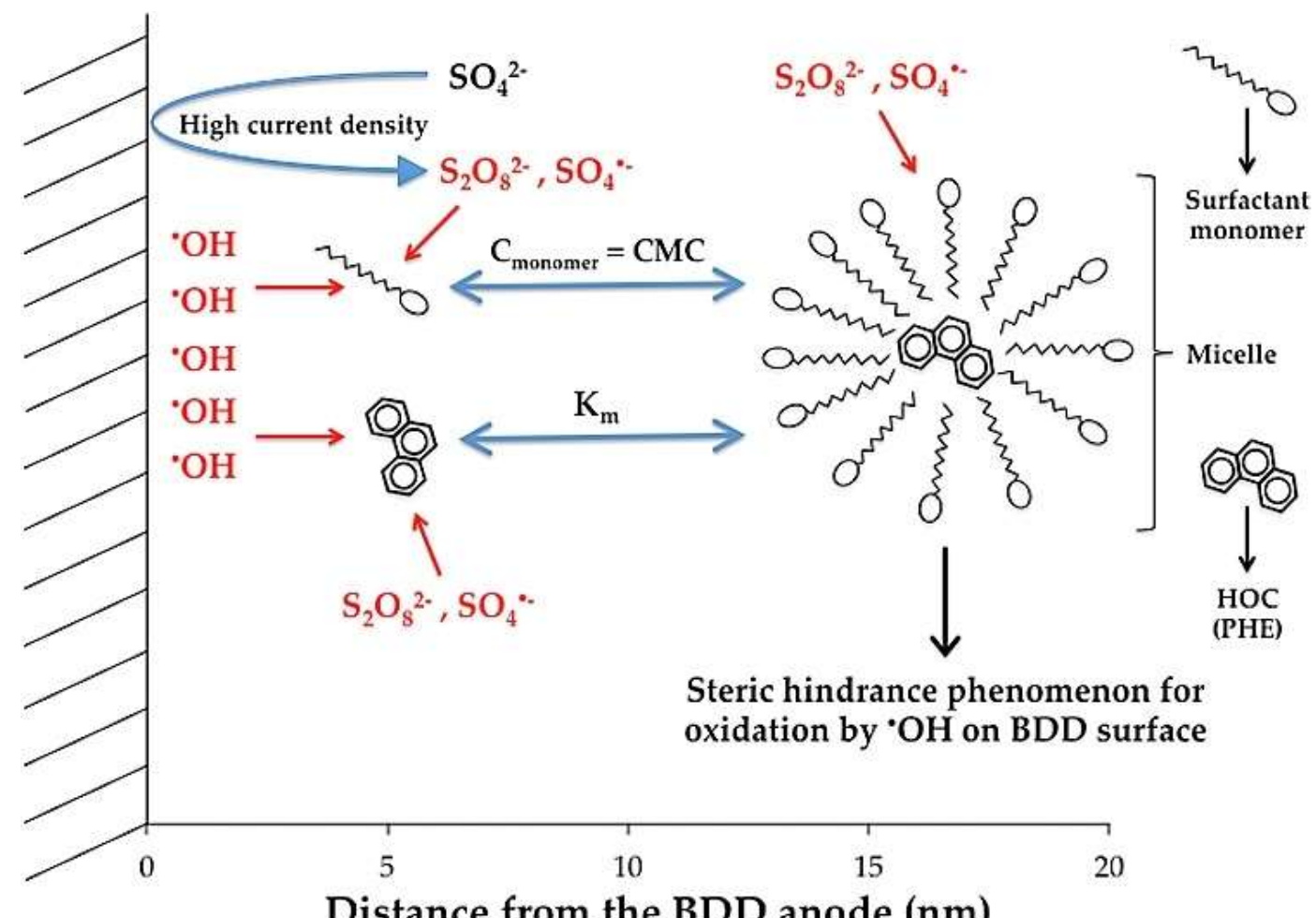

Distance from the BDD anode (nm)

Figure 3 - Schematic view of oxidation mechanisms occurring during the treatment of a soil washing solution (containing phenanthrene (PHE) as hydrophobic organic compound (HOC)) by anodic oxidation using boron-doped (BDD) anode. Reprinted from [23]. processes also strongly depend on extracting agent characteristics and concentration. Extracting agents influence the adsorption of pollutants onto photocatalysts and thus, the availability of 474 pollutants for oxidant species [1]. Improved photocatalytic degradation of HOCs was observed 475 when using concentrations of surfactant below or close to the CMC [150]. Combination of 476 surfactant monomers with the surface of $\mathrm{TiO}_{2}$ by hydrophobic (non-ionic surfactants) or 477 electrostatic (cationic surfactants) interactions was reported to form a superficial hydrophobic 478 reactive monolayer in which $\mathrm{HOCs}$ have high affinity $[150,151,156]$. Less favourable effects 
were observed for photocatalytic degradation of more hydrophilic compounds such as oxidation

480 by-products [151]. It was attributed to the decrease of their availability for oxidant species 481 because of the lower fraction of organic compounds implanted in the superficial hydrophobic 482 reactive monolayer (lower $K_{m}$ ) and/or a different locus of implementation of these organic 483 compounds inside this monolayer (closer to the hydrophilic heads of surfactants) (Figure 4). At 484 high surfactant concentration, photocatalytic degradation of HOCs strongly decreases due to 485 the hydroxyl radical scavengers as well as competitive partition of HOCs within micelles in the 486 bulk (that prevent reaction at the surface of the photocatalyst). Competition between surfactants 487 and HOCs for the occupation of active sites on the catalyst surface may also have strong adverse 488 effects [150,151,157]. Similar effects of concentration-dependant inhibition have been 489 observed when using CDs as extracting agent. Low concentration of CDs promotes the 490 photocatalytic degradation of HOC having high inclusion constant with CDs [158-160], while 491 high $\mathrm{CD}$ concentration hinders target pollutant degradation [62,139]. Unfortunately, SW 492 solutions usually contain high concentration of extracting agent. Interestingly, a lower 493 inhibitory effect was observed when using surfactants with bigger hydrated polar head, due to 494 the reduction of surfactant adsorption at the surface of the catalyst $[18,112]$. 
496

497

498

499

500

501

502

503

504

505

506

507

508

509

510

511

512

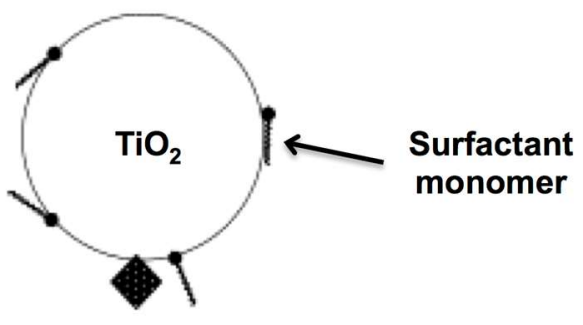

\section{Superficial} hydrophobic reactive monolayer

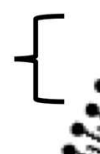

$\mathrm{TiO}_{2}$

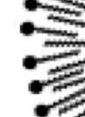

TiO
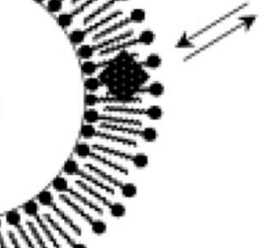

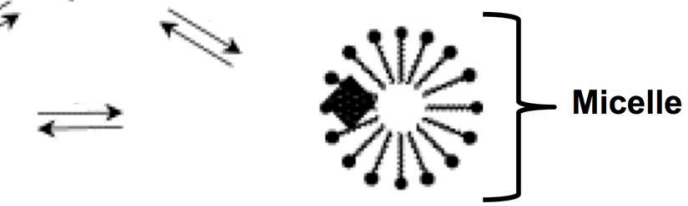

A

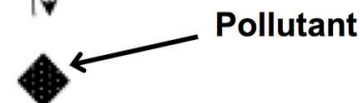

Figure 4 -Partition equilibria of target pollutants during the treatment of a SW solution by a $\mathrm{TiO}_{2}$-based photocatalytic process. Reprinted from [1]. .

Some other non-AOPs chemical oxidation processes have also been applied to the treatment of SW solution, particularly ozone, activated persulfate $[135,136,161,162]$, and electrochemical processes using active electrodes that do not produce hydroxyl radicals $[128,163]$. Lower effectiveness for the removal of target pollutants has been reported because of the generation of weaker oxidant species [1]. For example, degradation kinetic rates observed for the removal of PAH from SW solutions by electro-oxidation using graphite electrodes were in the range $0.02-0.2 \mathrm{~h}^{-1}[21,164]$. As regards to ozone, it was observed significant removal of PAH and chlorophenols from SW solutions (45-65\% removal) only when using high doses (> $\left.500 \mathrm{mg} \mathrm{O}_{3} \mathrm{~L}^{-1}\right)[165,166]$. Besides, it was reported that high concentration of surfactant decreases gas-liquid mass transfer for both (semi)-volatile pollutants and ozone, thus reducing the effectiveness of the ozone process [167].

\section{III.2.2 - Effectiveness for the recovery of extracting agents}


SW solution reuse by implementing a degradation process means that the aim is to

514 achieve both maximum removal of target pollutants and minimum degradation of extracting agents [1]. Thus, the treated SW solution might keep similar extraction capacity than a fresh SW solution without addition of extracting agents. However, two main issues are involved: (i) the protective environment for target pollutants formed by surfactant micelles and CDs, which usually decreases the availability of target pollutants for degradation ( $K_{m}$ and $K_{C D}$ are crucial parameters), (ii) the degradation of organic compounds in a non-selective way [1]. optimizing operating conditions of AOPs in order to promote the degradation of target pollutants and decrease the degradation rate of extracting agents. Even if hydroxyl radicals are considered as non-selective oxidants, different reaction kinetics with target pollutants and other extracting agents are obtained according to their chemical structure. For example, perfluorinated surfactants present the interesting characteristic to be highly recalcitrant to oxidation by hydroxyl radicals, however, they are considered as toxic persistent organic pollutants and they cannot be used for soil remediation by SW [168]. Aromatic compounds are also considered as highly reactive species [110]. A slower degradation rate of extracting agents compared to aromatic target pollutants can be used for partial recovery of extracting agents. As complete mineralization of target pollutants involves longer treatment time and higher degradation rate of extracting agents [1], only degradation of pollutants is usually considered.

532 Therefore, the toxicity of degradation by-products $[169,170]$ should also be assessed. Mousset 533 et al. [145] observed that a second SW step with a partially oxidized SW solution (containing 534 PAHs and TW80 as EA) by the EF process did not affect negatively the soil microbial activity, compared to the use of a fresh SW solution. This result was ascribed to the production of 536 hydroxylated by-products with higher biodegradability and solubility than initial compounds 
As regards to Fenton-based processes, promising results have been observed by using

539 CDs as extracting agents. The formation of a ternary complex CD-pollutant-Fe ${ }^{2+}$ allows

540 improving the availability of target pollutants towards hydroxyl radicals and higher degradation

541 kinetics of target pollutants were achieved compared to CDs $[144,154]$. By using the EF process,

542 better selective degradation was also achieved when using HPCD instead of TW80 as extracting 543 agent [144].

544 During photocatalytic processes, the formation of micelles in the bulk reduces the 545 availability of surfactants towards oxidant species generated on the photocatalyst surface $546[150,151,157]$ (Figure 4). Even if it might be considered as an interesting behaviour for 547 minimizing the degradation rates of EAs, it was observed to do not improve the selectivity of 548 the process. In fact, much lower degradation kinetic of target pollutants is usually also observed 549 because of the partitioning within micelles. Thus, it was actually reported higher rate of recovery of TX100 after full removal of a target pollutant (pentachlorophenol) when a low concentration of TX100 was used [150].

Processes based on the activation of persulfates using iron ions or thermal activation have also been recently developed for the treatment of SW solution. Compared to hydroxyl radicals, sulfate radicals present some more selective features that might be useful for achieving selective degradation of target pollutants $[136,172]$.

During anodic oxidation processes, it has been reported that low current density strongly

558 micelles on the anode surface. Lower degradation of extracting agents also results from the 559 decrease of mediated oxidation in the bulk at low current density $[23,155]$. Thus, free extra560 micellar target pollutants, continuously released in the solution (according to $K_{m}$ ) can be more 561 selectively degraded [23] (Figure 3). 


\begin{tabular}{|c|c|c|c|c|}
\hline Process & $\begin{array}{l}\text { Pollutants (P) } \\
\quad\left(\mathrm{mg} \mathrm{L}^{-1}\right)\end{array}$ & $\begin{array}{l}\text { Extracting agent } \\
\quad\left(\text { EA) }\left(\mathrm{g} \mathrm{L}^{-1}\right)\right.\end{array}$ & Effectiveness & Ref \\
\hline Photocatalysis & $\begin{array}{l}\text { Dibenzothiophene } \\
\quad(0.3-1.3)\end{array}$ & $\begin{array}{c}\mathrm{TX} 100^{1} \\
(0.14-0.25)\end{array}$ & $\begin{array}{l}\text { Full degradation of } \mathrm{P} / \\
\text { none degradation of } \mathrm{EA}\end{array}$ & [173] \\
\hline $\mathrm{EF}$ & $\begin{array}{l}\mathrm{PHE}^{2} \\
(17.8)\end{array}$ & $\begin{array}{l}\mathrm{HPCD}^{3} \\
\quad(10)\end{array}$ & $\begin{array}{l}\text { Full degradation of } \mathrm{P} / \\
10 \% \text { degradation of EA }\end{array}$ & [144] \\
\hline $\begin{array}{l}\text { Electro- } \\
\text { oxidation } \\
\text { (graphite } \\
\text { electrodes) }\end{array}$ & $\begin{array}{l}\mathrm{PHE}^{2} \\
(35)\end{array}$ & $\begin{array}{l}\mathrm{TW}^{4} 80^{4} \\
(10)\end{array}$ & $\begin{array}{c}95 \% \text { removal of } \mathrm{P} / \\
\text { Similar extraction } \\
\text { capacity of the treated } \\
\text { solution }\end{array}$ & [174] \\
\hline $\begin{array}{l}\text { Electro- } \\
\text { oxidation } \\
\text { (graphite } \\
\text { electrodes) }\end{array}$ & $\mathrm{PHE}^{2}$ & $\begin{array}{l}\mathrm{HPCD}^{3} \\
(1.0)\end{array}$ & $\begin{array}{c}\text { Full removal of } \mathrm{P} / \\
\text { Similar extraction } \\
\text { capacity of the treated } \\
\text { solution }\end{array}$ & [164] \\
\hline Fenton & $\begin{array}{l}\mathrm{p}-\mathrm{Cresol} \\
\quad(20)\end{array}$ & $\begin{array}{l}\text { TW804 } \\
(0.86)\end{array}$ & $\begin{array}{l}\text { Full degradation of P / } \\
10 \% \text { degradation of EA }\end{array}$ & [175] \\
\hline $\begin{array}{l}\text { Activated } \\
\text { persulfate }\end{array}$ & Nitrobenzene & $\begin{array}{l}\mathrm{SDBS}^{5} \\
(8.2)\end{array}$ & $\begin{array}{l}\text { Better selective } \\
\text { degradation than with } \\
\text { the Fenton process }\end{array}$ & [161] \\
\hline $\begin{array}{c}\text { Anodic } \\
\text { oxidation } \\
\left(\mathrm{BDD}^{6} \text { anode }\right)\end{array}$ & $\begin{array}{l}\text { PAHs from real } \\
\text { SW solution } \\
(1-5)\end{array}$ & $\begin{array}{c}\mathrm{TW} 80^{4} \\
(6.6)\end{array}$ & $\begin{array}{l}75-90 \% \text { removal of } \mathrm{P} / \\
\text { Similar extraction } \\
\text { capacity of the treated } \\
\text { solution }\end{array}$ & {$[23]$} \\
\hline $\begin{array}{l}\text { Activated } \\
\text { persulfate }\end{array}$ & $\begin{array}{c}\mathrm{PHE}^{2} \\
(10)\end{array}$ & $\begin{array}{l}\mathrm{TW} 80^{4} \\
(10)\end{array}$ & $\begin{array}{c}96 \% \text { removal of } \mathrm{P} / 20 \% \\
\text { removal of EA }\end{array}$ & [176] \\
\hline Fenton & $\begin{array}{c}\mathrm{COCs}^{7} \text { from real } \\
\text { SF solution } \\
(3700)\end{array}$ & $\begin{array}{c}\text { E-Mulse } 3^{\circledR} \\
(11)\end{array}$ & $\begin{array}{c}>80 \% \text { removal of } \mathrm{P} / \\
\text { Similar extraction } \\
\text { capacity of the treated } \\
\text { solution }\end{array}$ & [177] \\
\hline
\end{tabular}

${ }^{1}$ Triton X 100; ${ }^{2}$ Phenanthrene; ${ }^{3}$ Hydroxypropyl- $\beta$-cyclodextrin; ${ }^{4}$ Tween ${ }^{\circledR} 80 ;{ }^{5}$ Sodium

566 dodecybenzenesulfonate; ${ }^{6}$ Boron-doped diamond; ${ }^{7}$ Chlorinated organic compounds

However, contradictory results are also observed and the details of mechanisms leading

569 to the selective removal of pollutants solubilized within micelles are not fully understood.

570 Further development of selective degradation processes depends on the better understanding

571 and control of degradation mechanisms and kinetics, for which the nature and concentration of

572 EAs, target pollutants, and oxidant species have a crucial effect [172]. 
It is also worth noting that the critical parameter is not the amount of extracting agent

574 recovered but the extraction power of the treated solution. Important differences are usually 575 observed because of analysis artefacts of extracting agents, generation of degradation by576 products still solubilized in micelles and production of extracting agent by-products with 577 extracting properties [1]. For example, it was observed that a partially oxidized solution (by 578 using the EF process) containing 11\% less of HPCD than the initial solution achieved slightly 579 higher PAH removal from soil than a fresh HPCD solution [145]. This result was ascribed to 580 the extraction capacity of hydroxylated HPCD (degradation by-products) with an internal 581 hydrophobic space that remained intact. Interestingly, Dominguez et al. [177] also reported that 582 Fenton oxidation of a SF solution led to $>99 \%$ degradation of an additive of a commercial 583 extracting agent (E-Mulse $3^{\circledR}$ ), however, the equivalent surfactant concentration was only 584 decreased by $40-50 \%$, the interfacial tension of the solution was not altered and the extraction capacity of the solution remained constant. On the contrary, the reduction of $21 \%$ of the TW 80 concentration during the EF treatment of a SW solution strongly decreased the extraction power of the partially oxidized solution compared to a fresh TW80 solution [145]. Such results might

588 be ascribed to the artefacts in analysis of extracting agents (detection of degradation by589 products identified as TW80 while they have lower extraction capacity).

591 III.3 - Soil washing solution reuse or total removal of the organic load? The example of 592 the anodic oxidation process

594 solutions by anodic oxidation [22,23]. First, it was observed that treating a real SW solution 595 (with TW80 as EA) by anodic oxidation at low current density $\left(1.8 \mathrm{~mA} \mathrm{~cm}{ }^{-2}\right)$ during a long 596 treatment time $(23 \mathrm{~h})$ lead to the selective degradation of PAHs as target pollutants and allow 597 the recovery of the extraction capacity of the treated SW solution [23]. It was also emphasized 
that a high surfactant concentration improves the selective degradation of target pollutants with only a slight decrease of degradation kinetics of PAHs. Therefore, high concentration of surfactant might be used in order to increase the transfer of PAHs from the soil-sorbed fraction to the washing solution. In fact, the consumption of an additional amount of surfactant might be compensated by the high rate of recovery of extracting agents during the treatment by anodic oxidation at low current density. A second treatment strategy has been reported for the removal 604 of the organic load of a synthetic SW solution containing PHE as target pollutant and TW80 as extracting agent [22]. It is based on the combination of anodic oxidation with a biological treatment.

It might be actually interesting to use these two different treatment strategies in a complementary way. A crucial advantage of anodic oxidation is the possibility to easily manage 609 the operating conditions, particularly the current density [178]. Thus, an anodic oxidation treatment system might be able to implement both strategies (Figure 5). First, low current 611 density might be initially used for the reuse of the SW solution. Then, when sufficient pollutant 612 removal rate from soil would be achieved, the same system might treat the SW solution at high 613 current density in order to remove the organic load with a possible combination with a 614 biological treatment.

However, a systematic analysis taking into consideration all the different parameters of such complex environmental engineering issue would be required for concluding on the best treatment strategy (e.g. using life cycle assessment). From data obtained, only a short cost618 benefit analysis can be performed on energy consumption, which is a critical parameter during 619 anodic oxidation. It was reported that SW solution treatment at low current density only 620 required $13.2 \mathrm{kWh} \mathrm{m}^{-3}$ for the reuse of the treated solution [23]. By considering the price of the 621 electricity as $0.12 € \mathrm{kWh}^{-1}$ (in France), it corresponds to an energy cost of $1.6 € \mathrm{~m}^{-3}$ of SW 622 solution treated. Considering a price for TW80 at $4.0 € \mathrm{~kg}^{-1}$, it means that $1 \mathrm{~m}^{3}$ of a solution at 
$6235.0 \mathrm{mM}$ of TW80 $\left(6.6 \mathrm{~g} \mathrm{~L}^{-1}\right)$ would cost $26 €$. Therefore, the saving arising from the reuse of

624 the SW solution may compensate costs related to energy consumption of anodic oxidation. For

625 comparison, the energy consumption was $39 \mathrm{kWh}$ per $\mathrm{kg}$ of COD removed when using anodic

626 oxidation at high current density for the removal of the organic load. By considering $3 \mathrm{~h}$ of pre-

627 treatment (29\% COD removal of an initial solution at $\left.2.7 \mathrm{~g} \mathrm{~L}^{-1}\right)$, it corresponds to a consumption

628 of $30.5 \mathrm{kWh} \mathrm{m}^{-3}\left(3.7 € \mathrm{~m}^{-3}\right)$ [22]. This value is much higher than the energy consumption

629 required for SW solution reuse. Moreover, the energy consumption of the post-biological

630 treatment are not considered. However, a final step for the removal of the organic load from

631 SW solutions would be always required prior discharge in order to avoid any contamination of

632 the aquatic environment.

633

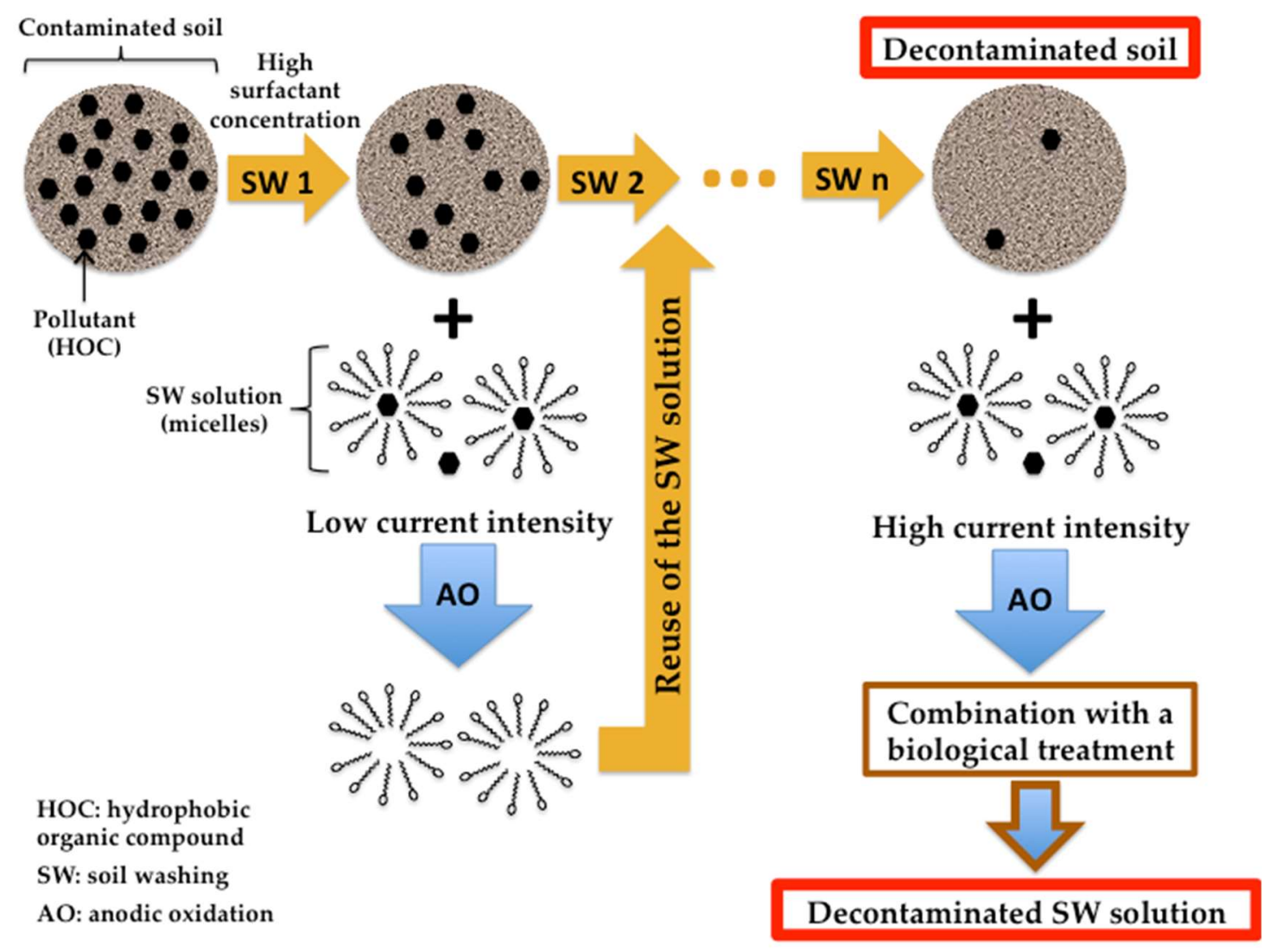

Figure 5 - Treatment strategy for soil remediation using soil washing and anodic oxidation processes.

636 Anodic oxidation at low current intensity allows the reuse of the soil washing solution for $n$ soil washing 
steps. Anodic oxidation at high current intensity combined with a biological treatment allows the removal of the organic load for final disposal of the soil washing solution.

\section{IV - Discussion}

Several technologies have been critically reviewed in this article (Figure 6). The choice of the most suitable technique depends strongly on characteristics of the SW solution (Table 3). Air stripping and related technologies (such as vacuum extraction or pervaporation) allows the effective and selective removal of compounds such as trichloroethylene or perchloroethylene from SW solutions. The choice of an adapted organic solvent for a liquid-liquid extraction can lead to an effective extraction of HOCs in the organic phase while a large amount of extracting agents is also recovered. The first drawback is that foaming issues have to be managed. The disposal of the contaminated solvent also represents a critical drawback for the sustainability of the process. Besides, the adsorption process appeared as a promising process for the selective separation of target pollutants from SW solutions. Whatever the separation process used, high concentrations of extracting agent usually reduce separation effectiveness due to the partition of target pollutants in the micellar pseudo-phase or inclusion complex with CDs ( $K_{m}$ or $K_{C D}$ are crucial parameters). Therefore, the optimal conditions for SW (high concentration of extracting agent and high $K_{m}$ or $K_{C D}$ ) have adverse effects on selective separation processes. Furthermore, a post-treatment of the contaminated air/sorbent/solvent is required, thus increasing the global cost of the whole treatment strategy.

Optimization of operating parameters for degradation processes can also lead to higher degradation rates of target pollutants compared to extracting agents. These results are mainly ascribed to the different reactivity of target pollutants and extracting agents with oxidant species. The heterogeneous production of hydroxyl radicals at the anode surface during the anodic 
662 oxidation process was also reported to promote selective oxidation of target pollutants when

663 using low current density. Compared to separation process, a lower amount of extracting agents

664 is usually recovered by using degradation processes but the great advantage lies in the

665 simultaneous degradation of target pollutants. In case of partial recovery of EAs, periodic re-

666 injection of fresh extracting agents might be considered for maintaining the extraction capacity

667 of the reused solution.

668

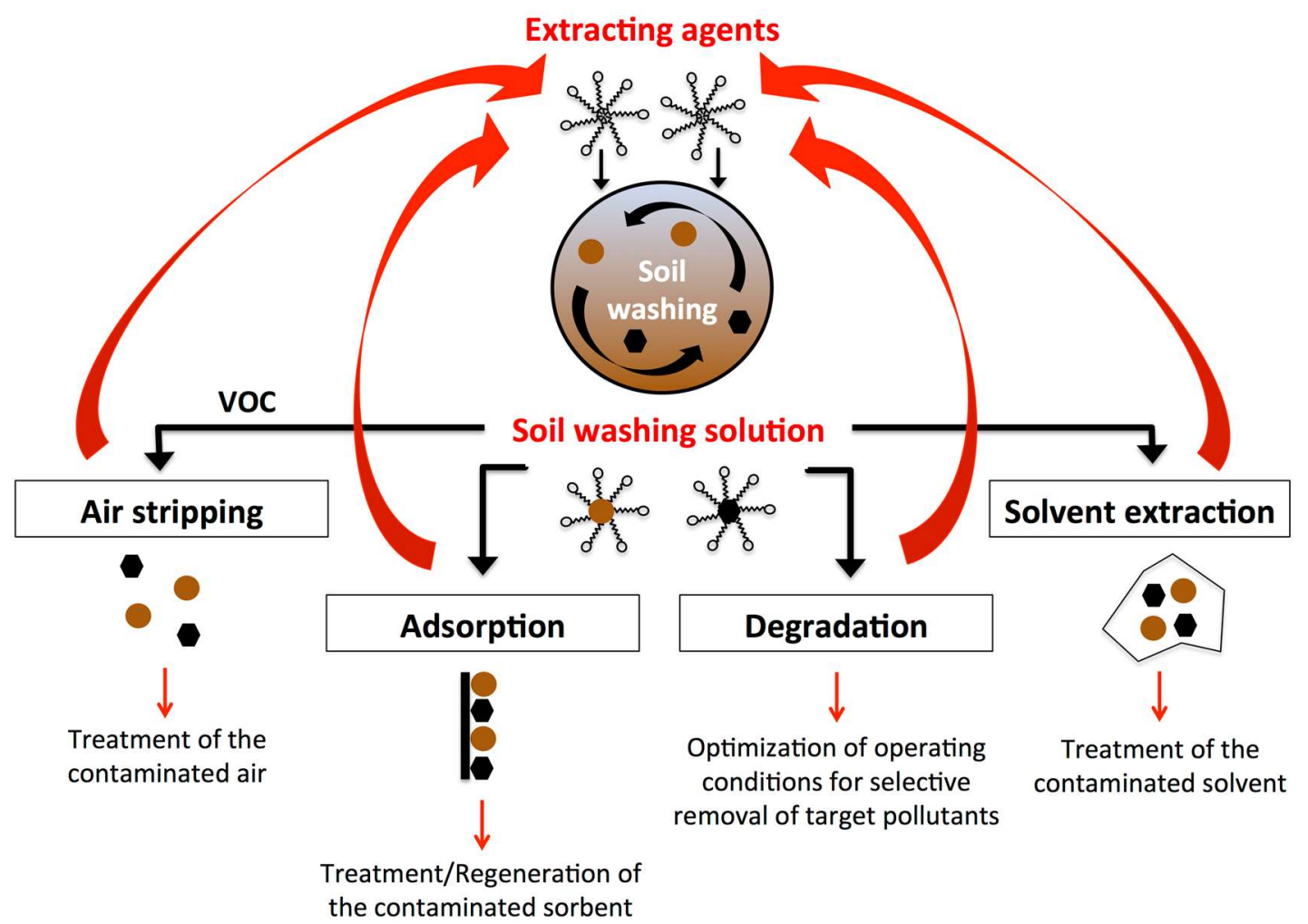

669

670

Figure 6 - Treatment strategies for the recovery of extracting agents from contaminated soil washing

672 solutions.

Table 3 - Important operating conditions, target pollutant and extracting agent characteristics to consider according to the choice of the process used. CMC: critical micelle concentration; $\mathrm{K}_{\mathrm{m}}$ : micellar phase / aqueous phase partition coefficient; $\mathrm{K}_{\mathrm{CD}}$ : complex stability (or equilibrium) constant between 


\begin{tabular}{|c|c|c|c|}
\hline Process & $\begin{array}{l}\text { Important target } \\
\text { pollutant } \\
\text { characteristics } \\
\text { (optimal*) }\end{array}$ & $\begin{array}{l}\text { Important } \\
\text { extracting agent } \\
\text { characteristics } \\
\text { (optimal*) }\end{array}$ & $\begin{array}{l}\text { Important operating } \\
\text { conditions }\end{array}$ \\
\hline Air stripping & $\begin{array}{c}\text { Henry constant (low), } \\
\text { saturated vapor } \\
\text { pressure (high), } \\
K_{m} / K_{C D} \text { (low) }\end{array}$ & $\begin{array}{c}\text { Henry constant } \\
\text { (high), concentration } \\
\text { (low), } K_{m} / K_{C D} \text { (low) }\end{array}$ & $\begin{array}{c}\text { Limitation of foaming } \\
\text { (hollow fiber membranes, } \\
\text { vacuum processes) }\end{array}$ \\
\hline $\begin{array}{l}\text { Liquid-liquid } \\
\text { extraction }\end{array}$ & $\begin{array}{c}\text { Solvent-water } \\
\text { partition coefficient } \\
\text { (high), } K_{m} / K_{C D} \text { (low) }\end{array}$ & $\begin{array}{l}\text { Solvent-water } \\
\text { partition coefficient } \\
\text { (low), concentration } \\
\text { (low), } K_{m} / K_{C D} \text { (low) }\end{array}$ & $\begin{array}{l}\text { Limitation of } \\
\text { emulsification and amount } \\
\text { of solvent used (hollow } \\
\text { fiber membranes), highly } \\
\text { hydrophobic solvent }\end{array}$ \\
\hline $\begin{array}{l}\text { Membrane } \\
\text { processes }\end{array}$ & $\begin{array}{l}\text { Oil-containing } \\
\text { mixture (for selective } \\
\text { removal), } K_{m}\end{array}$ & $\begin{array}{l}\text { Concentration, } K_{m}, \\
\text { micelle size, CMC, } \\
\text { effect on } \\
\text { concentration } \\
\text { polarization }\end{array}$ & $\begin{array}{l}\text { Ultrafiltration (for micellar- } \\
\text { enhanced ultrafiltration), } \\
\text { fouling control (depending } \\
\text { on fouling materials) }\end{array}$ \\
\hline $\begin{array}{l}\text { Adsorption } \\
\text { processes }\end{array}$ & $\begin{array}{c}\text { Partition coefficient } \\
\text { on the sorbent } \\
\text { material (high), } \\
K_{m} / K_{C D} \text { (low) }\end{array}$ & $\begin{array}{l}\text { Partition coefficient } \\
\text { on the sorbent } \\
\text { material (low), } \\
\text { concentration, } K_{m} / K_{C D} \\
\text { (low) }\end{array}$ & $\begin{array}{l}\text { Sorbent material (pore size } \\
\text { distribution) and dose }\end{array}$ \\
\hline $\begin{array}{l}\text { Degradation } \\
\text { processes }\end{array}$ & $\begin{array}{l}\text { Reactivity (high), } \\
\qquad K_{m} / K_{C D}\end{array}$ & $\begin{array}{c}\text { Reactivity (low), } \\
\text { concentration, nature, } \\
K_{m} / K_{C D}\end{array}$ & $\begin{array}{l}\text { Optimized for selective } \\
\text { degradation of target } \\
\text { pollutants }\end{array}$ \\
\hline
\end{tabular}

$677 *$ Optimal conditions for the selective removal of target pollutants from SW solutions (different from optimal 678 conditions for the SW step) Further studies on real contaminated soils are required in order to assess the efficiency 681 of these processes at real field scale. The complex mixture of compounds in real SW solutions 682 involves strong competition mechanisms, which often reduce separation and degradation 683 effectiveness. Several studies are performed on synthetic SW solutions, without taking into 684 consideration the influence of clay and silt particles. Additional studies would be required in 685 order to a better understand the impact of these compounds on selective separation or 686 degradation processes. The extraction capacity of fresh and recovered SW solutions should also 687 be always assessed with real contaminated soils. The use of artificial or spiked soils usually 688 leads to a strong overestimation of the efficiency due to a lower sequestration of pollutants. For 
example, it has been observed that ageing and weathering of tar oil-contaminated soil leads to the formation of resinated materials which strongly reduce mass transfer of PAHs from soil to the washing solution $[10,189]$. Finally, there is an important lack of data in the scientific literature on pilot or field scale applications in this context of most of processes (particularly selective degradation and adsorption processes). These data will be crucial for assessing the real potential of these treatment strategies.

Nature and concentration of the extracting agent used during the SW step are also critical parameters for the treatment of SW solutions (Table 3). Thus, the implementation of optimal operating conditions for SW should also take into consideration the impact of the nature and concentration of the extracting agent chosen on the treatment of the SW solution. Particularly, its capacity to be recovered and reused for several SW steps should be assessed in order to improve the sustainability of the whole process. Optimizing the recovery of extracting agents requires taking into consideration all the steps involved in the soil remediation process (Figure 1).

\section{V - Conclusions and Recommendations}

EA-enhanced SW is an effective treatment strategy for the removal of organic pollutants when it is applied to a suitable contaminated soil. The optimization of operating parameters (nature of the EA, concentration and other operating conditions) is the most direct way to save EAs, improve extraction effectiveness and implement a cost-effective process. However, an appropriate treatment strategy of the SW solution allowing the recovery of extracting agents and the reuse of the SW solution is also a crucial step in order to save large amounts of extracting agents and to improve the sustainability and ecological footprint of the whole remediation process. 
714 solutions but further studies are necessary in order to assess the robustness of each process and 715 the possibility for scaling up. Then, the choice of the most suitable technology (and operating 716 conditions) depends on the physicochemical characteristics of each specific SW solution. It is 717 therefore crucial to adapt the process to the specificity of each kind of SW solution (nature and 718 concentrations of target pollutants, extracting agents and other compounds mobilized during 719 the SW step).

Finally, the choice of the most suitable strategy for the treatment of a SW solution

721 should be based on a cost-benefit analysis and life cycle analysis should be performed for 722 selecting the most suitable strategy. Selective separation/degradation of target pollutants 723 involve the implementation of costly processes (in terms of reagents and/or energy 724 consumption). Therefore, these additional costs have to be compared to the savings coming 725 from the reuse of the SW solution. The development of effective processes for recovery of 726 extracting agents could also promote (i) the use of more expensive extracting agents with both 727 higher extraction capacity and lower soil toxicity and (ii) the implementation of several 728 successive SW steps in order to achieve higher removal rates of HOCs from real contaminated 729 soils.

\section{Acknowledgements:}

732 Clément Trellu would like to acknowledge the Education, Audiovisual and Culture Executive Agency 733 of the European Commission for financial support. Clément Trellu was a Doctoral research fellow of 734 the Erasmus Mundus Joint Doctorate programme $\mathrm{ETeCoS}^{3}$ (Environmental Technologies for 735 Contaminated Solids, Soils and Sediments) under the grant agreement FPA no. 2010-0009.

\section{References}


[1] C. Trellu, E. Mousset, Y. Pechaud, D. Huguenot, E.D. van Hullebusch, G. Esposito, M.A. Oturan, Removal of hydrophobic organic pollutants from soil washing/flushing solutions: A critical review, J. Hazard. Mater. 306 (2016) 149-174. https://doi.org/10.1016/j.jhazmat.2015.12.008.

[2] BASOL - Ministère de l'Écologie, du Développement Durable et de l'Énergie, (n.d.). http://basol.developpement-durable.gouv.fr/ (accessed July 1, 2016).

[3] Martin. Alexander, How Toxic Are Toxic Chemicals in Soil?, Environ. Sci. Technol. 29 (1995) 2713-2717. https://doi.org/10.1021/es00011a003.

[4] P. Roudier, Techniques de réhabilitation des sites et sols pollués, www.techniquesingenieurs.fr, 2005.

[5] F.J. Stevenson, Humus Chemistry: Genesis, Composition, Reactions, Wiley Interscience, New York, 1982.

[6] M. Schnitzer, S.U. Khan, Soil Organic Matter, Elsevier Science Publishers B.V., 1978.

[7] G. Cornelissen, Ö. Gustafsson, T.D. Bucheli, M.T.O. Jonker, A.A. Koelmans, P.C.M. van Noort, Extensive Sorption of Organic Compounds to Black Carbon, Coal, and Kerogen in Sediments and Soils: Mechanisms and Consequences for Distribution, Bioaccumulation, and Biodegradation, Environ. Sci. Technol. 39 (2005) 6881-6895. https://doi.org/10.1021/es050191b.

[8] J.C. White, J.W. Kelsey, P.B. Hatzinger, M. Alexander, Factors affecting sequestration and bioavailability of phenanthrene in soils, Environ. Toxicol. Chem. 16 (1997) 20402045. https://doi.org/10.1002/etc.5620161008.

[9] L. Hong, U. Ghosh, T. Mahajan, R.N. Zare, R.G. Luthy, PAH Sorption Mechanism and Partitioning Behavior in Lampblack-Impacted Soils from Former Oil-Gas Plant Sites, Environ. Sci. Technol. 37 (2003) 3625-3634. https://doi.org/10.1021/es0262683.

[10] C. Trellu, A. Miltner, R. Gallo, D. Huguenot, E.D. van Hullebusch, G. Esposito, M.A. Oturan, M. Kästner, Characteristics of PAH tar oil contaminated soils-Black particles, resins and implications for treatment strategies, J. Hazard. Mater. 327 (2017) 206-215. https://doi.org/10.1016/j.jhazmat.2016.12.062.

[11] E. Mousset, M.A. Oturan, E.D. van Hullebusch, G. Guibaud, G. Esposito, Soil washing/flushing treatments of organic pollutants enhanced by cyclodextrins and integrated treatments: State of the art, Crit. Rev. Environ. Sci. Technol. 44 (2014) 705795. https://doi.org/10.1080/10643389.2012.741307.

[12] C.N. Mulligan, R.N. Yong, B.F. Gibbs, Surfactant-enhanced remediation of contaminated soil: A review, Eng. Geol. 60 (2001) 371-380. https://doi.org/10.1016/S0013-7952(00)00117-4.

[13] O. Atteia, E.D.C. Estrada, H. Bertin, Soil flushing: A review of the origin of efficiency variability, Rev. Environ. Sci. Biotechnol. 12 (2013) 379-389. https://doi.org/10.1007/s11157-013-9316-0.

[14] X. Mao, R. Jiang, W. Xiao, J. Yu, Use of surfactants for the remediation of contaminated soils: A review, J. Hazard. Mater. 285 (2015) 419-435. https://doi.org/10.1016/j.jhazmat.2014.12.009.

[15] S. Laha, B. Tansel, A. Ussawarujikulchai, Surfactant-soil interactions during surfactantamended remediation of contaminated soils by hydrophobic organic compounds: A review, J. Environ. Manage. 90 (2009) 95-100. 
https://doi.org/10.1016/j.jenvman.2008.08.006.

783

784

785

786

787

788

789

790

791

792

793

794

795

796

797

798

799

800

801

802

803

804

805

806

807

808

809

810

811

812

813

814

815

816

817

818

819

820

821

822

823

824

825

[16] S. Paria, Surfactant-enhanced remediation of organic contaminated soil and water, Adv. Colloid Interface Sci. 138 (2008) 24-58. https://doi.org/10.1016/j.cis.2007.11.001.

[17] E.V. dos Santos, C. Sáez, P. Cañizares, D.R. da Silva, C.A. Martínez-Huitle, M.A. Rodrigo, Treatment of ex-situ soil-washing fluids polluted with petroleum by anodic oxidation, photolysis, sonolysis and combined approaches, Chem. Eng. J. (n.d.). https://doi.org/10.1016/j.cej.2016.05.015.

[18] D. Fabbri, A. Crime, M. Davezza, C. Medana, C. Baiocchi, A.B. Prevot, E. Pramauro, Surfactant-assisted removal of swep residues from soil and photocatalytic treatment of the washing wastes, Appl. Catal. B Environ. 92 (2009) 318-325. https://doi.org/10.1016/j.apcatb.2009.08.010.

[19] L.H. Tran, P. Drogui, G. Mercier, J.F. Blais, Electrochemical degradation of polycyclic aromatic hydrocarbons in creosote solution using ruthenium oxide on titanium expanded mesh anode, J. Hazard. Mater. 164 (2009) 1118-1129. https://doi.org/10.1016/j.jhazmat.2008.09.012.

[20] M. Davezza, D. Fabbri, A.B. Prevot, E. Pramauro, Removal of alkylphenols from polluted sites using surfactant-assisted soil washing and photocatalysis, Environ. Sci. Pollut. Res. 18 (2011) 783-789. https://doi.org/10.1007/s11356-010-0427-7.

[21] M.T. Alcántara, J. Gómez, M. Pazos, M.A. Sanromán, PAHs soil decontamination in two steps: Desorption and electrochemical treatment, J. Hazard. Mater. 166 (2009) 462468. https://doi.org/10.1016/j.jhazmat.2008.11.050.

[22] C. Trellu, O. Ganzenko, S. Papirio, Y. Pechaud, N. Oturan, D. Huguenot, E.D. van Hullebusch, G. Esposito, M.A. Oturan, Combination of anodic oxidation and biological treatment for the removal of phenanthrene and Tween 80 from soil washing solution, Chem. Eng. J. 306 (2016) 588-596. https://doi.org/10.1016/j.cej.2016.07.108.

[23] C. Trellu, N. Oturan, Y. Pechaud, E.D. van Hullebusch, G. Esposito, M.A. Oturan, Anodic oxidation of surfactants and organic compounds entrapped in micelles Selective degradation mechanisms and soil washing solution reuse, Water Res. 118 (2017) 1-11. https://doi.org/10.1016/j.watres.2017.04.013.

[24] M. Cheng, G. Zeng, D. Huang, C. Yang, C. Lai, C. Zhang, Y. Liu, Advantages and challenges of Tween 80 surfactant-enhanced technologies for the remediation of soils contaminated with hydrophobic organic compounds, Chem. Eng. J. 314 (2017) 98-113. https://doi.org/10.1016/j.cej.2016.12.135.

[25] R.D. Villa, A.G. Trovó, R.F.P. Nogueira, Soil remediation using a coupled process: Soil washing with surfactant followed by photo-Fenton oxidation, J. Hazard. Mater. 174 (2010) 770-775. https://doi.org/10.1016/j.jhazmat.2009.09.118.

[26] M. Lechuga, M. Fernández-Serrano, E. Jurado, J. Núñez-Olea, F. Ríos, Acute toxicity of anionic and non-ionic surfactants to aquatic organisms, Ecotoxicol. Environ. Saf. 125 (2016) 1-8. https://doi.org/10.1016/j.ecoenv.2015.11.027.

[27] T. Ivanković, J. Hrenović, Surfactants in the environment, Arh. Hig. Rada Toksikol. 61 (2010) 95-110. https://doi.org/10.2478/10004-1254-61-2010-1943.

[28] S.S. Cameotra, J.M. Bollag, Biosurfactant-enhanced bioremediation of polycyclic aromatic hydrocarbons, Crit. Rev. Environ. Sci. Technol. 33 (2003) 111-126. https://doi.org/10.1080/10643380390814505. 
[29] C.C. Lai, Y.C. Huang, Y.H. Wei, J.S. Chang, Biosurfactant-enhanced removal of total petroleum hydrocarbons from contaminated soil, J. Hazard. Mater. 167 (2009) 609-614. https://doi.org/10.1016/j.jhazmat.2009.01.017.

[30] M. Bustamante, N. Durán, M.C. Diez, Biosurfactants are useful tools for the bioremediation of contaminated soil: A review, J. Soil Sci. Plant Nutr. 12 (2012).

[31] C.N. Mulligan, Environmental applications for biosurfactants, Environ. Pollut. 133 (2005) 183-198. https://doi.org/10.1016/j.envpol.2004.06.009.

[32] G.R. Tick, F. Lourenso, A.L. Wood, M.L. Brusseau, Pilot-scale demonstration of cyclodextrin as a solubility-enhancement agent for remediation of a tetrachloroethenecontaminated aquifer, Environ. Sci. Technol. 37 (2003) 5829-5834. https://doi.org/10.1021/es030417f.

[33] F.M. Menger, C.A. Littau, Gemini surfactants: a new class of self-assembling molecules, J. Am. Chem. Soc. 115 (1993) 10083-10090. https://doi.org/10.1021/ja00075a025.

[34] J. Maire, A. Coyer, N. Fatin-Rouge, Surfactant foam technology for in situ removal of heavy chlorinated compounds-DNAPLs, J. Hazard. Mater. 299 (2015) 630-638. https://doi.org/10.1016/j.jhazmat.2015.07.071.

[35] R.G. Luthy, D.A. Dzombak, C.A. Peters, S.B. Roy, A. Ramaswami, D.V. Nakles, B.R. Nott, Remediating tar-contaminated soils at manufactured gas plant sites, Environ. Sci. Technol. 28 (1994) 266-276. https://doi.org/10.1021/es00055a002.

[36] U. Ghosh, J.W. Talley, R.G. Luthy, Particle-Scale Investigation of PAH Desorption Kinetics and Thermodynamics from Sediment, Environ. Sci. Technol. 35 (2001) 34683475. https://doi.org/10.1021/es0105820.

[37] U. Ghosh, J.R. Zimmerman, R.G. Luthy, PCB and PAH Speciation among Particle Types in Contaminated Harbor Sediments and Effects on PAH Bioavailability, Environ. Sci. Technol. 37 (2003) 2209-2217. https://doi.org/10.1021/es020833k.

[38] D. Huguenot, E. Mousset, E.D. van Hullebusch, M.A. Oturan, Combination of surfactant enhanced soil washing and electro-Fenton process for the treatment of soils contaminated by petroleum hydrocarbons, J. Environ. Manage. 153 (2015) 40-47. https://doi.org/10.1016/j.jenvman.2015.01.037.

[39] X. Liang, C. Guo, C. Liao, S. Liu, L.Y. Wick, D. Peng, X. Yi, G. Lu, H. Yin, Z. Lin, Z. Dang, Drivers and applications of integrated clean-up technologies for surfactantenhanced remediation of environments contaminated with polycyclic aromatic hydrocarbons (PAHs), Environ. Pollut. 225 (2017) 129-140. https://doi.org/10.1016/j.envpol.2017.03.045.

[40] N. Fatin-Rouge, Contaminant Mobilization from Polluted Soils: Behavior and Reuse of Leaching Solutions, in: E.D. van Hullebusch, D. Huguenot, Y. Pechaud, M.-O.

Simonnot, S. Colombano (Eds.), Environ. Soil Remediat. Rehabil. Exist. Innov. Solut., Springer International Publishing, Cham, 2020: pp. 1-59. https://doi.org/10.1007/978-3030-40348-5_1.

[41] L.M. Abriola, C.D. Drummond, E.J. Hahn, K.F. Hayes, T.C.G. Kibbey, L.D. Lemke, K.D. Pennell, E.A. Petrovskis, C.A. Ramsburg, K.M. Rathfelder, Pilot-scale demonstration of surfactant-enhanced PCE solubilization at the Bachman road site. 1. Site characterization and test design, Environ. Sci. Technol. 39 (2005) 1778-1790. https://doi.org/10.1021/es0495819. 
[42] C.A. Ramsburg, K.D. Pennell, L.M. Abriola, G. Daniels, C.D. Drummond, M. Gamache, H.L. Hsu, E.A. Petrovskis, K.M. Rathfelder, J.L. Ryder, T.P. Yavaraski, Pilot-scale demonstration of surfactant-enhanced PCE solubilization at the Bachman road site. 2. System operation and evaluation, Environ. Sci. Technol. 39 (2005) 17911801. https://doi.org/10.1021/es049563r.

[43] K. Oma, A. Clarke, M. Megehee, D. Wilson, Soil Cleanup by Surfactant Washing .3. Design and Evaluation of the Integrated Pilot-Scale Surfactant Recycle System, Sep. Sci. Technol. 28 (1993) 2319-2349. https://doi.org/10.1080/01496399308019741.

[44] H. Cheng, D.A. Sabatini, Separation of organic compounds from surfactant solutions: A review, Sep. Sci. Technol. 42 (2007) 453-475. https://doi.org/10.1080/01496390601120664.

[45] K.M. Lipe, D.A. Sabatini, M.A. Hasegawa, J.H. Harwell, Micellarenhanced ultrafiltration and air stripping for surfactant-contaminant separation and surfactant reuse, Ground Water Monit. 16 (1996) 85-92.

[46] T.C.G. Kibbey, K.D. Pennell, K.F. Hayes, Application of sieve-tray air strippers to the treatment of surfactant-containing wastewaters, Aiche J. 47 (2001) 1461-1470. https://doi.org/10.1002/aic.690470621.

[47] J.H. O’Haver, R. Walk, B. Kitiyanan, J.H. Harwell, D.A. Sabatini, Packed column and hollow fiber air stripping of a contaminant-surfactant stream, J. Environ. Eng.-Asce. 130 (2004) 4-11. https://doi.org/10.1061/(ASCE)0733-9372(2004)130:1(4).

[48] D.A. Sabatini, J.H. Harwell, M. Hasegawa, R. Knox, Membrane processes and surfactant-enhanced subsurface remediation: Results of a field demonstration, J. Membr. Sci. 151 (1998) 87-98. https://doi.org/10.1016/S0376-7388(98)00170-7.

[49] W.J. Blanford, M.L. Barackman, T.B. Boving, E.J. Klingel, G.R. Johnson, M.L. Brusseau, Cyclodextrin-enhanced vertical flushing of a trichloroethene contaminated aquifer, Ground Water Monit. Remediat. 21 (2001) 58-66. https://doi.org/10.1111/j.1745-6592.2001.tb00631.x.

[50] L.H. Chen, Y.L. Lee, The effects of a surfactant on the mass transfer in spray-tower extraction column, Chem. Eng. J. 73 (1999) 77-81. https://doi.org/10.1016/S13858947(99)00028-5.

[51] E. Tucker, S. Christian, Vapor-pressure studies of benzene-cyclodextrin inclusion complexes in aqueous-solution, J. Am. Chem. Soc. 106 (1984) 1942-1945. https://doi.org/10.1021/ja00319a007.

[52] E. Tucker, S. Christian, Precise vapor-pressure measurements of the solubilization of benzene by aqueous sodium octylsulfate solutions, Faraday Symp. Chem. Soc. (1982) $11-24$.

[53] U.N. Choori, J.F. Scamehorn, J.H. O’Haver, J.H. Harwell, Removal of volatile organic compounds horn surfactant solutions by flash vacuum stripping in a packed column, Ground Water Monit. Remediat. 18 (1998) 157-165. https://doi.org/10.1111/j.17456592.1998.tb00175.x.

[54] J.-S. Jiang, L.M. Vane, S.K. Sikdar, Recovery of VOCs from surfactant solutions by pervaporation, J. Membr. Sci. 136 (1997) 233-247. https://doi.org/10.1016/S03767388(97)00169-5.

[55] L.M. Vane, L. Hitchens, F.R. Alvarez, E.L. Giroux, Field demonstration of pervaporation for the separation of volatile organic compounds from a surfactant-based 
soil remediation fluid, J. Hazard. Mater. 81 (2001) 141-166.

https://doi.org/10.1016/S0304-3894(00)00337-X.

[56] I. Abou-Nemeh, A. Das, A. Saraf, K.K. Sirkar, A composite hollow fiber membranebased pervaporation process for separation of VOCs from aqueous surfactant solutions, J. Membr. Sci. 158 (1999) 187-209. https://doi.org/10.1016/S0376-7388(99)00011-3.

[57] L. Hitchens, L.M. Vane, F.R. Alvarez, VOC removal from water and surfactant solutions by pervaporation: a pilot study, Sep. Purif. Technol. 24 (2001) 67-84. https://doi.org/10.1016/S1383-5866(00)00214-8.

[58] M.A. Hasegawa, D.A. Sabatini, J.H. Harwell, Liquid-liquid, extraction for surfactantcontaminant separation and surfactant reuse, J. Environ. Eng.-Asce. 123 (1997) 691697. https://doi.org/10.1061/(ASCE)0733-9372(1997)123:7(691).

[59] A. Clarke, K. Oma, M. Megehee, D. Wilson, Soil Cleanup by Surfactant Washing .2. Design and Evaluation of the Components of the Pilot-Scale Surfactant Recycle System, Sep. Sci. Technol. 28 (1993) 2103-2135. https://doi.org/10.1080/01496399308016738.

[60] H.F. Cheng, D.A. Sabatini, T.C.G. Kibbey, Solvent extraction for separating micellarsolubilized contaminants and anionic surfactants, Environ. Sci. Technol. 35 (2001) 2995-3001. https://doi.org/10.1021/es002057r.

[61] J.H. O'Haver, B. Kitiyanan, J.H. Harwell, D.A. Sabatini, The use of liquid-liquid extraction for the separation of organic contaminants from groundwater-surfactant streams., Abstr. Pap. Am. Chem. Soc. 215 (1998) U672-U673.

[62] A. Petitgirard, M. Djehiche, J. Persello, P. Fievet, N. Fatin-Rouge, PAH contaminated soil remediation by reusing an aqueous solution of cyclodextrins, Chemosphere. 75 (2009) 714-718. https://doi.org/10.1016/j.chemosphere.2009.01.072.

[63] M.K. Purkait, S. DasGupta, S. De, Removal of dye from wastewater using micellarenhanced ultrafiltration and recovery of surfactant, Sep. Purif. Technol. 37 (2004) 8192. https://doi.org/10.1016/j.seppur.2003.08.005.

[64] C.C. Ang, A.S. Abdul, Evaluation of an Ultrafiltration Method for Surfactant Recovery and Reuse During In Situ Washing of Contaminated Sites: Laboratory and Field Studies, Ground Water Monit. Remediat. 14 (1994) 160-171. https://doi.org/10.1111/j.1745-6592.1994.tb00477.x.

[65] S. Tian, C. Zhang, D. Huang, R. Wang, G. Zeng, M. Yan, W. Xiong, C. Zhou, M. Cheng, W. Xue, Y. Yang, W. Wang, Recent progress in sustainable technologies for adsorptive and reactive removal of sulfonamides, Chem. Eng. J. 389 (2020) 123423. https://doi.org/10.1016/j.cej.2019.123423.

[66] C.K. Ahn, S.H. Woo, J.M. Park, Selective adsorption of phenanthrene in nonionicanionic surfactant mixtures using activated carbon, Chem. Eng. J. 158 (2010) 115-119. https://doi.org/10.1016/j.cej.2009.12.014.

[67] C.K. Ahn, Y.M. Kim, S.H. Woo, J.M. Park, Selective adsorption of phenanthrene dissolved in surfactant solution using activated carbon, Chemosphere. 69 (2007) 16811688. https://doi.org/10.1016/j.chemosphere.2007.06.018.

[68] W. Zhou, X. Wang, C. Chen, L. Zhu, Removal of polycyclic aromatic hydrocarbons from surfactant solutions by selective sorption with organo-bentonite, Chem. Eng. J. 233 (2013) 251-257. https://doi.org/10.1016/j.cej.2013.08.040. 
[69] M. Zhang, C. Zhao, J. Li, L. Xu, F. Wei, D. Hou, B. Sarkar, Y.S. Ok, Organo-layered double hydroxides for the removal of polycyclic aromatic hydrocarbons from soil washing effluents containing high concentrations of surfactants, J. Hazard. Mater. 373 (2019) 678-686. https://doi.org/10.1016/j.jhazmat.2019.03.126.

[70] J. Liu, J. Chen, L. Jiang, X. Yin, Adsorption of mixed polycyclic aromatic hydrocarbons in surfactant solutions by activated carbon, J. Ind. Eng. Chem. 20 (2014) 616-623. https://doi.org/10.1016/j.jiec.2013.05.024.

[71] H. Gao, W.J. Blanford, Partitioning behavior of trichloroethlyene in cyclodextrinwater-granular-activated carbon systems, Environ. Eng. Sci. 29 (2012) 533-539. https://doi.org/10.1089/ees.2011.0451.

[72] K. Sniegowski, M. Vanhecke, P.J. D’Huys, L. Braeken, Potential of activated carbon to recover randomly-methylated- $\beta$-cyclodextrin solution from washing water originating from in situ soil flushing, Sci. Total Environ. (2014). https://doi.org/10.1016/j.scitotenv.2013.11.112.

[73] J. Liu, W. Chen, Remediation of phenanthrene contaminated soils by nonionic-anionic surfactant washing coupled with activated carbon adsorption, Water Sci. Technol. J. Int. Assoc. Water Pollut. Res. 72 (2015) 1552-1560. https://doi.org/10.2166/wst.2015.357.

[74] W. Zhou, Q. Yang, C. Chen, Q. Wu, L. Zhu, Fixed-bed study and modeling of selective phenanthrene removal from surfactant solutions, Colloids Surf. Physicochem. Eng. Asp. 470 (2015) 100-107. https://doi.org/10.1016/j.colsurfa.2015.01.077.

[75] J. Liu, J. Chen, L. Jiang, X. Wang, Adsorption of fluoranthene in surfactant solution on activated carbon: equilibrium, thermodynamic, kinetic studies, Environ. Sci. Pollut. Res. Int. 21 (2014) 1809-1818. https://doi.org/10.1007/s11356-013-2075-1.

[76] J.-S. Yang, K. Baek, T.-S. Kwon, J.-W. Yang, Adsorption of chlorinated solvents in nonionic surfactant solutions with activated carbon in a fixed bed, J. Ind. Eng. Chem. 15 (2009) 777-779. https://doi.org/10.1016/j.jiec.2009.09.027.

[77] C.K. Ahn, Y.M. Kim, S.H. Woo, J.M. Park, Soil washing using various nonionic surfactants and their recovery by selective adsorption with activated carbon, J. Hazard. Mater. 154 (2008) 153-160. https://doi.org/10.1016/j.jhazmat.2007.10.006.

[78] J. Wan, L. Chai, X. Lu, Y. Lin, S. Zhang, Remediation of hexachlorobenzene contaminated soils by rhamnolipid enhanced soil washing coupled with activated carbon selective adsorption, J. Hazard. Mater. 189 (2011) 458-464. https://doi.org/10.1016/j.jhazmat.2011.02.055.

[79] J.M. Rosas, A. Santos, A. Romero, Soil-Washing Effluent Treatment by Selective Adsorption of Toxic Organic Contaminants on Activated Carbon, Water. Air. Soil Pollut. 224 (2013). https://doi.org/10.1007/s11270-013-1506-4.

[80] H. Li, R. Qu, C. Li, W. Guo, X. Han, F. He, Y. Ma, B. Xing, Selective removal of polycyclic aromatic hydrocarbons (PAHs) from soil washing effluents using biochars produced at different pyrolytic temperatures, Bioresour. Technol. 163 (2014) 193-198. https://doi.org/10.1016/j.biortech.2014.04.042.

[81] X. Zheng, H. Lin, Y. Tao, H. Zhang, Selective adsorption of phenanthrene dissolved in Tween 80 solution using activated carbon derived from walnut shells, Chemosphere. 208 (2018) 951-959. https://doi.org/10.1016/j.chemosphere.2018.06.025.

[82] S. Zhang, Y. He, L. Wu, J. Wan, M. Ye, T. Long, Z. Yan, X. Jiang, Y. Lin, X. Lu, Remediation of Organochlorine Pesticide-Contaminated Soils by Surfactant-Enhanced 
Washing Combined with Activated Carbon Selective Adsorption, Pedosphere. 29 (2019) 400-408. https://doi.org/10.1016/S1002-0160(17)60328-X.

[83] Y. Zeng, M. Zhang, D. Lin, K. Yang, Selective removal of phenanthrene from SDBS or TX100 solution by sorption of resin SP850, Chem. Eng. J. 388 (2020) 124191. https://doi.org/10.1016/j.cej.2020.124191.

[84] C.K. Ahn, M.W. Lee, D.S. Lee, S.H. Woo, J.M. Park, Mathematical evaluation of activated carbon adsorption for surfactant recovery in a soil washing process, J. Hazard. Mater. 160 (2008) 13-19. https://doi.org/10.1016/j.jhazmat.2008.02.074.

[85] J.A. Banuelos, O. Garcia-Rodriguez, F.J. Rodriguez-Valadez, J. Manriquez, E. Bustos, A. Rodriguez, L.A. Godinez, Cathodic polarization effect on the electro-Fenton regeneration of activated carbon, J. Appl. Electrochem. 45 (2015) 523-531. https://doi.org/10.1007/s10800-015-0815-2.

[86] P.M. Alvarez, F.J. Beltran, V. Gomez-Serrano, J. Jaramillo, E.M. Rodriguez, Comparison between thermal and ozone regenerations of spent activated carbon exhausted with phenol, Water Res. 38 (2004) 2155-2165. https://doi.org/10.1016/j.watres.2004.01.030.

[87] M.I. Bautista-Toledo, J. Rivera-Utrilla, J.D. Méndez-Díaz, M. Sánchez-Polo, F. Carrasco-Marín, Removal of the surfactant sodium dodecylbenzenesulfonate from water by processes based on adsorption/bioadsorption and biodegradation, J. Colloid Interface Sci. (2014). https://doi.org/10.1016/j.jcis.2013.12.001.

[88] G. Marchal, K.E.C. Smith, A. Rein, A. Winding, S. Trapp, U.G. Karlson, Comparing the desorption and biodegradation of low concentrations of phenanthrene sorbed to activated carbon, biochar and compost, Chemosphere. 90 (2013) 1767-1778. https://doi.org/10.1016/j.chemosphere.2012.07.048.

[89] X. Liu, X. Quan, L. Bo, S. Chen, Y. Zhao, Simultaneous pentachlorophenol decomposition and granular activated carbon regeneration assisted by microwave irradiation, Carbon. 42 (2004) 415-422. https://doi.org/10.1016/j.carbon.2003.12.032.

[90] J.A. Bañuelos, F.J. Rodríguez, J. Manríquez Rocha, E. Bustos, A. Rodríguez, J.C. Cruz, L.G. Arriaga, L.A. Godínez, Novel electro-Fenton approach for regeneration of activated carbon, Environ. Sci. Technol. 47 (2013) 7927-7933. https://doi.org/10.1021/es401320e.

[91] C. Trellu, N. Oturan, F.K. Keita, C. Fourdrin, Y. Pechaud, M.A. Oturan, Regeneration of Activated Carbon Fiber by the Electro-Fenton Process, Environ. Sci. Technol. 52 (2018) 7450-7457. https://doi.org/10.1021/acs.est.8b01554.

[92] J.L. Li, B.H. Chen, Surfactant-mediated biodegradation of polycyclic aromatic hydrocarbons, Materials. 2 (2009) 76-94. https://doi.org/10.3390/ma2010076.

[93] S. Berselli, G. Milone, P. Canepa, D. Di Gioia, F. Fava, Effects of cyclodextrins, humic substances, and rhamnolipids on the washing of a historically contaminated soil and on the aerobic bioremediation of the resulting effluents, Biotechnol. Bioeng. 88 (2004) 111-120. https://doi.org/10.1002/bit.20218.

[94] J.M. Wang, R.M. Maier, M.L. Brusseau, Influence of hydroxypropyl-beta-cyclodextrin (HPCD) on the bioavailability and biodegradation of pyrene, Chemosphere. 60 (2005) 725-728. https://doi.org/10.1016/j.chemosphere.2005.03.031.

[95] J.L. Li, B.H. Chen, Effect of nonionic surfactants on biodegradation of phenanthrene by a marine bacteria of Neptunomonas naphthovorans, J. Hazard. Mater. 162 (2009) 66- 
[96] R.R. Navarro, Y. Iimura, H. Ichikawa, K. Tatsumi, Treatment of PAHs in contaminated soil by extraction with aqueous DNA followed by biodegradation with a pure culture of Sphingomonas sp., Chemosphere. 73 (2008) 1414-1419.

1053 https://doi.org/10.1016/j.chemosphere.2008.08.004.

1055

1056

1057

1058

1059

1060

1061

1062

1063

1064

1065

1066

1067

1068

1069

1070

1071

1072

1073

1074

1075

1076

1077

1078

1079

1080

1081

1082

1083

1084

1085

1086

1087

1088

1089

1090

1091

1092

1093

[97] S. Guha, P.R. Jaffe, Biodegradation kinetics of phenanthrene partitioned into the micellar phase of nonionic surfactants, Environ. Sci. Technol. 30 (1996) 605-611. https://doi.org/10.1021/es950385z.

[98] S. Guha, P.R. Jaffe, Bioavailability of hydrophobic compounds partitioned into the micellar phase of nonionic surfactants, Environ. Sci. Technol. 30 (1996) 1382-1391. https://doi.org/10.1021/es950694p.

[99] Y.M. Zhang, W.J. Maier, R.M. Miller, Effect of rhamnolipids on the dissolution, bioavailability and biodegradation of phenanthrene, Environ. Sci. Technol. 31 (1997) 2211-2217. https://doi.org/10.1021/es960687g.

[100] S. Bury, C. Miller, Effect of micellar solubilization on biodegradation rates of hydrocarbons, Environ. Sci. Technol. 27 (1993) 104-110.

https://doi.org/10.1021/es00038a010.

[101] F. Volkering, A. Breure, J. Vanandel, W. Rulkens, Influence of nonionic surfactants on bioavailability and biodegradation, Appl. Environ. Microbiol. 61 (1995) 1699-1705.

[102] Y. Liu, G. Zeng, H. Zhong, Z. Wang, Z. Liu, M. Cheng, G. Liu, X. Yang, S. Liu, Effect of rhamnolipid solubilization on hexadecane bioavailability: enhancement or reduction?, J. Hazard. Mater. 322 (2017) 394-401. https://doi.org/10.1016/j.jhazmat.2016.10.025.

[103] A. Tiehm, Degradation of polycyclic aromatic hydrocarbons in the presence of synthetic surfactants, Appl. Environ. Microbiol. 60 (1994) 258-263.

[104] D. Jin, X. Jiang, X. Jing, Z. Ou, Effects of concentration, head group, and structure of surfactants on the degradation of phenanthrene, J. Hazard. Mater. 144 (2007) 215-221. https://doi.org/10.1016/j.jhazmat.2006.10.012.

[105] S. Laha, R. Luthy, Effects of nonionic surfactants on the solubilization and mineralization of phenanthrene in soil-water systems, Biotechnol. Bioeng. 40 (1992) 1367-1380. https://doi.org/10.1002/bit.260401111.

[106] C. Vipulanandan, X.P. Ren, Enhanced solubility and biodegradation of naphthalene with biosurfactant, J. Environ. Eng.-Asce. 126 (2000) 629-634. https://doi.org/10.1061/(ASCE)0733-9372(2000)126:7(629).

[107] F. Gharibzadeh, R. Rezaei Kalantary, S. Nasseri, A. Esrafili, A. Azari, Reuse of polycyclic aromatic hydrocarbons (PAHs) contaminated soil washing effluent by bioaugmentation/biostimulation process, Sep. Purif. Technol. 168 (2016) 248-256. https://doi.org/10.1016/j.seppur.2016.05.022.

[108] M.A. Oturan, J.J. Aaron, Advanced oxidation processes in water/wastewater treatment: principles and applications. A review, Crit. Rev. Environ. Sci. Technol. 44 (2014) 2577-2641. https://doi.org/10.1080/10643389.2013.829765.

[109] W.M. Latimer, Oxidation Potentials, Prentice-Hall, 1952.

[110] E. Brillas, I. Sirés, M.A. Oturan, Electro-Fenton process and related electrochemical technologies based on Fenton's reaction chemistry, Chem. Rev. 109 (2009) 6570-6631. 
https://doi.org/10.1021/cr900136g.

1095

1096

1097

1098

1099

1100

1101

1102

1103

1104

1105

1106

1107

1108

1109

1110

1111

1112

1113

1114

1115

1116

1117

1118

1119

1120

1121

1122

1123

1124

1125

1126

1127

1128

1129

1130

1131

1132

1133

1134

1135

1136

1137

1138

[111] E. Mousset, N. Oturan, M.A. Oturan, An unprecedented route of OH radical reactivity evidenced by an electrocatalytical process: Ipso-substitution with perhalogenocarbon compounds, Appl. Catal. B Environ. 226 (2018) 135-146. https://doi.org/10.1016/j.apcatb.2017.12.028.

[112] M. Davezza, D. Fabbri, E. Pramauro, A.B. Prevot, Photocatalytic degradation of bentazone in soil washing wastes containing alkylpolyoxyethylene surfactants, Chemosphere. 86 (2012) 335-340. https://doi.org/10.1016/j.chemosphere.2011.09.011.

[113] E.V. dos Santos, C. Sáez, P. Cañizares, C.A. Martínez-Huitle, M.A. Rodrigo, UV assisted electrochemical technologies for the removal of oxyfluorfen from soil washing wastes, Chem. Eng. J. 318 (2017) 2-9. https://doi.org/10.1016/j.cej.2016.03.015.

[114] P.T. Almazán-Sánchez, S. Cotillas, C. Sáez, M.J. Solache-Ríos, V. Martínez-Miranda, P. Cañizares, I. Linares-Hernández, M.A. Rodrigo, Removal of pendimethalin from soil washing effluents using electrolytic and electro-irradiated technologies based on diamond anodes, Appl. Catal. B Environ. 213 (2017) 190-197. https://doi.org/10.1016/j.apcatb.2017.05.008.

[115] M. Muñoz-Morales, M. Braojos, C. Sáez, P. Cañizares, M.A. Rodrigo, Remediation of soils polluted with lindane using surfactant-aided soil washing and electrochemical oxidation, J. Hazard. Mater. 339 (2017) 232-238. https://doi.org/10.1016/j.jhazmat.2017.06.021.

[116] M. Muñoz-Morales, C. Sáez, P. Cañizares, M.A. Rodrigo, Anodic oxidation for the remediation of soils polluted with perchloroethylene, J. Chem. Technol. Biotechnol. 94 (2019) 288-294. https://doi.org/10.1002/jctb.5774.

[117] Y. Liu, M. Cheng, Z. Liu, G. Zeng, H. Zhong, M. Chen, C. Zhou, W. Xiong, B. Shao, B. Song, Heterogeneous Fenton-like catalyst for treatment of rhamnolipid-solubilized hexadecane wastewater, Chemosphere. 236 (2019) 124387. https://doi.org/10.1016/j.chemosphere.2019.124387.

[118] F. Liu, N. Oturan, H. Zhang, M.A. Oturan, Soil washing in combination with electrochemical advanced oxidation for the remediation of synthetic soil heavily contaminated with diesel, Chemosphere. 249 (2020) 126176. https://doi.org/10.1016/j.chemosphere.2020.126176.

[119] M. Pera-Titus, V. Garcia-Molina, M.A. Banos, J. Gimenez, S. Esplugas, Degradation of chlorophenols by means of advanced oxidation processes: A general review, Appl. Catal. B-Environ. 47 (2004) 219-256. https://doi.org/10.1016/j.apcatb.2003.09.010.

[120] J.M. Herrmann, Heterogeneous photocatalysis: Fundamentals and applications to the removal of various types of aqueous pollutants, Catal. Today. 53 (1999) 115-129. https://doi.org/10.1016/S0920-5861(99)00107-8.

[121] K. Kabra, R. Chaudhary, R.L. Sawhney, Treatment of hazardous organic and inorganic compounds through aqueous-phase photocatalysis: A review, Ind. Eng. Chem. Res. 43 (2004) 7683-7696. https://doi.org/10.1021/ie0498551.

[122] M.A. Oturan, N. Oturan, M.C. Edelahi, F.I. Podvorica, K.E. Kacemi, Oxidative degradation of herbicide diuron in aqueous medium by Fenton's reaction based advanced oxidation processes, Chem. Eng. J. 171 (2011) 127-135. https://doi.org/10.1016/j.cej.2011.03.072.

[123] E.J. Ruiz, A. Hernández-Ramírez, J.M. Peralta-Hernández, C. Arias, E. Brillas, 
Application of solar photoelectro-Fenton technology to azo dyes mineralization: Effect of current density, Fe2+ and dye concentrations, Chem. Eng. J. 171 (2011) 385-392. https://doi.org/10.1016/j.cej.2011.03.004.

[124] J.J. Pignatello, Dark and photoassisted iron(3+)-catalyzed degradation of chlorophenoxy herbicides by hydrogen peroxide, Environ. Sci. Technol. 26 (1992) $944-$ 951. https://doi.org/10.1021/es00029a012.

[125] S. Ammar, M.A. Oturan, L. Labiadh, A. Guersalli, R. Abdelhedi, N. Oturan, E. Brillas, Degradation of tyrosol by a novel electro-Fenton process using pyrite as heterogeneous source of iron catalyst, Water Res. 74 (2015) 77-87. https://doi.org/10.1016/j.watres.2015.02.006.

[126] R. Matta, K. Hanna, S. Chiron, Fenton-like oxidation of 2,4,6-trinitrotoluene using different iron minerals, Sci. Total Environ. 385 (2007) 242-251. https://doi.org/10.1016/j.scitotenv.2007.06.030.

[127] C. Comninellis, Electrocatalysis in the electrochemical conversion/combustion of organic pollutants for waste-water treatment, Electrochimica Acta. 39 (1994) 18571862. https://doi.org/10.1016/0013-4686(94)85175-1.

[128] M. Panizza, G. Cerisola, Direct and mediated anodic oxidation of organic pollutants, Chem. Rev. 109 (2009) 6541-6569. https://doi.org/10.1021/cr9001319.

[129] M.A. Oturan, An ecologically effective water treatment technique using electrochemically generated hydroxyl radicals for in situ destruction of organic pollutants: Application to herbicide 2,4-D, J. Appl. Electrochem. 30 (2000) 475-482. https://doi.org/10.1023/A:1003994428571.

[130] I. Sirés, E. Brillas, M.A. Oturan, M.A. Rodrigo, M. Panizza, Electrochemical advanced oxidation processes: today and tomorrow. A review, Environ. Sci. Pollut. Res. 21 (2014) 8336-8367. https://doi.org/10.1007/s11356-014-2783-1.

[131] C. Comninellis, A. Nerini, Anodic oxidation of phenol in the presence of $\mathrm{NaCl}$ for waste-water treatment, J. Appl. Electrochem. 25 (1995) 23-28.

[132] E.V. Dos Santos, C. Sáez, C.A. Martínez-Huitle, P. Cañizares, M.A. Rodrigo, Combined soil washing and CDEO for the removal of atrazine from soils, J. Hazard. Mater. 300 (2015) 129-134. https://doi.org/10.1016/j.jhazmat.2015.06.064.

[133] S. Liu, C. Lai, B. Li, C. Zhang, M. Zhang, D. Huang, L. Qin, H. Yi, X. Liu, F. Huang, X. Zhou, L. Chen, Role of radical and non-radical pathway in activating persulfate for degradation of p-nitrophenol by sulfur-doped ordered mesoporous carbon, Chem. Eng. J. 384 (2020) 123304. https://doi.org/10.1016/j.cej.2019.123304.

[134] F. Qin, Y. Peng, G. Song, Q. Fang, R. Wang, C. Zhang, G. Zeng, D. Huang, C. Lai, Y. Zhou, X. Tan, M. Cheng, S. Liu, Degradation of sulfamethazine by biochar-supported bimetallic oxide/persulfate system in natural water: Performance and reaction mechanism, J. Hazard. Mater. 398 (2020) 122816. https://doi.org/10.1016/j.jhazmat.2020.122816.

[135] A. Shan, U. Farooq, S. Lyu, W.Q. Zaman, Z. Abbas, M. Ali, A. Idrees, P. Tang, M. Li, Y. Sun, Q. Sui, Efficient removal of trichloroethylene in surfactant amended solution by nano $\mathrm{Fe} 0$-Nickel bimetallic composite activated sodium persulfate process, Chem. Eng. J. 386 (2020) 123995. https://doi.org/10.1016/j.cej.2019.123995.

[136] Y. Qiu, M. Xu, Z. Sun, H. Li, Remediation of PAH-Contaminated Soil by Combining Surfactant Enhanced Soil Washing and Iron-Activated Persulfate Oxidation Process, 
Int. J. Environ. Res. Public. Health. 16 (2019). https://doi.org/10.3390/ijerph16030441.

[137] F. Chen, Z. Luo, G. Liu, Y. Yang, S. Zhang, J. Ma, Remediation of electronic waste polluted soil using a combination of persulfate oxidation and chemical washing, $J$. Environ. Manage. 204 (2017) 170-178. https://doi.org/10.1016/j.jenvman.2017.08.050.

[138] E. Pramauro, A.B. Prevot, M. Vincenti, R. Gamberini, Photocatalytic degradation of naphthalene in aqueous TiO2 dispersions: Effect of nonionic surfactants, Chemosphere. 36 (1998) 1523-1542. https://doi.org/10.1016/S0045-6535(97)10051-0.

[139] K. Hanna, C. de Brauer, P. Germain, J.M. Chovelon, C. Ferronato, Degradation of pentachlorophenol in cyclodextrin extraction effluent using a photocatalytic process, Sci. Total Environ. 332 (2004) 51-60. https://doi.org/10.1016/j.scitotenv.2004.04.022.

[140] N. Barrios, P. Sivov, D. D'Andrea, O. Nunez, Conditions for selective photocatalytic degradation of naphthalene in triton X-100 water solutions, Int. J. Chem. Kinet. 37 (2005) 414-419. https://doi.org/10.1002/kin.20094.

[141] D. Fabbri, A.B. Prevot, V. Zelano, M. Ginepro, E. Pramauro, Removal and degradation of aromatic compounds from a highly polluted site by coupling soil washing with photocatalysis, Chemosphere. 71 (2008) 59-65. https://doi.org/10.1016/j.chemosphere.2007.10.028.

[142] G. Yardin, S. Chiron, Photo-Fenton treatment of TNT contaminated soil extract solutions obtained by soil flushing with cyclodextrin, Chemosphere. 62 (2006) 13951402. https://doi.org/10.1016/j.chemosphere.2005.05.019.

[143] K. Hanna, S. Chiron, M.A. Oturan, Coupling enhanced water solubilization with cyclodextrin to indirect electrochemical treatment for pentachlorophenol contaminated soil remediation, Water Res. 39 (2005) 2763-2773. https://doi.org/10.1016/j.watres.2005.04.057.

[144] E. Mousset, N. Oturan, E.D. van Hullebusch, G. Guibaud, G. Esposito, M.A. Oturan, Influence of solubilizing agents (cyclodextrin or surfactant) on phenanthrene degradation by electro-Fenton process - study of soil washing recycling possibilities and environmental impact, Water Res. 48 (2014) 306-316. https://doi.org/10.1016/j.watres.2013.09.044.

[145] E. Mousset, D. Huguenot, E.D. van Hullebusch, N. Oturan, G. Guibaud, G. Esposito, M.A. Oturan, Impact of electrochemical treatment of soil washing solution on PAH degradation efficiency and soil respirometry, Environ. Pollut. 211 (2016) 354-362. https://doi.org/10.1016/j.envpol.2016.01.021.

[146] L.H. Tran, P. Drogui, G. Mercier, J.F. Blais, Comparison between Fenton oxidation process and electrochemical oxidation for PAH removal from an amphoteric surfactant solution, J. Appl. Electrochem. 40 (2010) 1493-1510. https://doi.org/10.1007/s10800010-0128-4.

[147] P. Westerhoff, G. Aiken, G. Amy, J. Debroux, Relationships between the structure of natural organic matter and its reactivity towards molecular ozone and hydroxyl radicals, Water Res. 33 (1999) 2265-2276. https://doi.org/10.1016/S0043-1354(98)00447-3.

[148] M.E. Lindsey, M.A. Tarr, Inhibition of hydroxyl radical reaction with aromatics by dissolved natural organic matter, Environ. Sci. Technol. 34 (2000) 444-449. https://doi.org/10.1021/es990457c.

[149] M.E. Lindsey, M.A. Tarr, Inhibited hydroxyl radical degradation of aromatic hydrocarbons in the presence of dissolved fulvic acid, Water Res. 34 (2000) 2385-2389. 
https://doi.org/10.1016/S0043-1354(99)00391-7.

1230

1231

1232

1233

1234

1235

1236

1237

1238

1239

1240

1241

1242

1243

1244

1245

1246

1247

1248

1249

1250

1251

1252

1253

1254

1255

1256

1257

1258

1259

1260

1261

1262

1263

1264

1265

1266

1267

1268

1269

1270

1271

1272

1273
[150] J.W. Liu, R. Han, H.T. Wang, Y. Zhao, Z. Chu, H.Y. Wu, Photoassisted degradation of pentachlorophenol in a simulated soil washing system containing nonionic surfactant Triton X-100 with La-B codoped TiO2 under visible and solar light irradiation, Appl. Catal. B Environ. 103 (2011) 470-478. https://doi.org/10.1016/j.apcatb.2011.02.013.

[151] D. Fabbri, A.B. Prevot, E. Pramauro, Effect of surfactant microstructures on photocatalytic degradation of phenol and chlorophenols, Appl. Catal. B Environ. 62 (2006) 21-27. https://doi.org/10.1016/j.apcatb.2005.06.011.

[152] W. Zheng, M.A. Tarr, Evidence for the existence of ternary complexes of iron, cyclodextrin, and hydrophobic guests in aqueous solution, J. Phys. Chem. B. 108 (2004) 10172-10176. https://doi.org/10.1021/jp0373806.

[153] W. Zheng, M.A. Tarr, Assessment of ternary iron-cyclodextrin-2-naphthol complexes using NMR and fluorescence spectroscopies, Spectrochim. Acta. A. Mol. Biomol. Spectrosc. 65 (2006) 1098-1103. https://doi.org/10.1016/j.saa.2006.02.010.

[154] M.E. Lindsey, G.X. Xu, J. Lu, M.A. Tarr, Enhanced Fenton degradation of hydrophobic organics by simultaneous iron and pollutant complexation with cyclodextrins, Sci. Total Environ. 307 (2003) 215-229. https://doi.org/10.1016/S0048-9697(02)00544-2.

[155] E.V. Dos Santos, C. Sáez, C.A. Martínez-Huitle, P. Cañizares, M.A. Rodrigo, The role of particle size on the conductive diamond electrochemical oxidation of soil-washing effluent polluted with atrazine, Electrochem. Commun. 55 (2015) 26-29. https://doi.org/10.1016/j.elecom.2015.03.003.

[156] Y. Zhang, H. Wu, J. Zhang, H. Wang, W. Lu, Enhanced photodegradation of pentachlorophenol by single and mixed cationic and nonionic surfactants, J. Hazard. Mater. 221-222 (2012) 92-99. https://doi.org/10.1016/j.jhazmat.2012.04.005.

[157] S. Sinha, N.G. Tapia Orozco, D.S. Acosta Ramirez, R. Rodriguez-Vazquez, Effect of surfactant on TiO2/UV mediated heterogeneous photocatalytic degradation of DDT in contaminated water, Crc Press-Taylor \& Francis Group, Boca Raton, 2009.

[158] P. Lu, F. Wu, N. Deng, Enhancement of TiO2 photocatalytic redox ability by $\beta$ cyclodextrin in suspended solutions, Appl. Catal. B Environ. 53 (2004) 87-93. https://doi.org/10.1016/j.apcatb.2004.04.016.

[159] G. Wang, F. Wu, X. Zhang, M. Luo, N. Deng, Enhanced TiO2 photocatalytic degradation of bisphenol $\mathrm{E}$ by $\beta$-cyclodextrin in suspended solutions, J. Hazard. Mater. 133 (2006) 85-91. https://doi.org/10.1016/j.jhazmat.2005.09.058.

[160] X. Zhang, F. Wu, Z. Wang, Y. Guo, N. Deng, Photocatalytic degradation of 4,4 'biphenol in $\mathrm{TiO} 2$ suspension in the presence of cyclodextrins: a trinity integrated mechanism, J. Mol. Catal. -Chem. 301 (2009) 134-139. https://doi.org/10.1016/j.molcata.2008.11.022.

[161] J. Yan, W. Gao, L. Qian, L. Han, Y. Chen, M. Chen, Remediation of Nitrobenzene Contaminated Soil by Combining Surfactant Enhanced Soil Washing and Effluent Oxidation with Persulfate, PLOS ONE. 10 (2015) e0132878. https://doi.org/10.1371/journal.pone.0132878.

[162] Y. Tao, M. Brigante, H. Zhang, G. Mailhot, Phenanthrene degradation using Fe(III)EDDS photoactivation under simulated solar light: A model for soil washing effluent treatment, Chemosphere. 236 (2019) 124366.

https://doi.org/10.1016/j.chemosphere.2019.124366. 
[163] A. Karaçali, M. Muñoz-Morales, S. Kalkan, B.K. Körbahti, C. Saez, P. Cañizares, M.A. Rodrigo, A comparison of the electrolysis of soil washing wastes with active and nonactive electrodes, Chemosphere. 225 (2019) 19-26. https://doi.org/10.1016/j.chemosphere.2019.02.175.

[164] J. Gómez, M.T. Alcántara, M. Pazos, M. Angeles Sanroman, Soil washing using cyclodextrins and their recovery by application of electrochemical technology, Chem. Eng. J. 159 (2010) 53-57. https://doi.org/10.1016/j.cej.2010.02.025.

[165] P. Haapea, T. Tuhkanen, Integrated treatment of PAH contaminated soil by soil washing, ozonation and biological treatment, J. Hazard. Mater. 136 (2006) 244-250. https://doi.org/10.1016/j.jhazmat.2005.12.033.

[166] P. Haapea, T. Tuhkanen, Aged chlorophenol contaminated soil's integrated treatment by ozonation, soil washing and biological methods, Environ. Technol. 26 (2005) 811819. https://doi.org/10.1080/09593332608618517.

[167] C.Y. Chiu, Y.H. Chen, Y.H. Huang, Removal of naphthalene in Brij 30-containing solution by ozonation using rotating packed bed, J. Hazard. Mater. 147 (2007) 732-737. https://doi.org/10.1016/j.jhazmat.2007.01.068.

[168] J.M. Quiroga, A. Riaza, M.A. Manzano, Chemical degradation of PCB in the contaminated soils slurry: Direct Fenton oxidation and desorption combined with the photo-Fenton process, J. Environ. Sci. Health Part -ToxicHazardous Subst. Environ. Eng. 44 (2009) 1120-1126. https://doi.org/10.1080/10934520903005145.

[169] A. Dirany, I. Sirés, N. Oturan, A. Özcan, M.A. Oturan, Electrochemical treatment of the antibiotic sulfachloropyridazine: Kinetics, reaction pathways, and toxicity evolution, Environ. Sci. Technol. 46 (2012) 4074-4082. https://doi.org/10.1021/es204621q.

[170] N. Oturan, S. Trajkovska, M.A. Oturan, M. Couderchet, J.J. Aaron, Study of the toxicity of diuron and its metabolites formed in aqueous medium during application of the electrochemical advanced oxidation process "electro-Fenton," Chemosphere. 73 (2008) 1550-1556. https://doi.org/10.1016/j.chemosphere.2008.07.082.

[171] C. Trellu, Y. Péchaud, N. Oturan, E. Mousset, D. Huguenot, E.D. van Hullebusch, G. Esposito, M.A. Oturan, Comparative study on the removal of humic acids from drinking water by anodic oxidation and electro-Fenton processes: Mineralization efficiency and modelling, Appl. Catal. B Environ. 194 (2016) 32-41. https://doi.org/10.1016/j.apcatb.2016.04.039.

[172] I. Bouzid, J. Maire, E. Brunol, S. Caradec, N. Fatin-Rouge, Compatibility of surfactants with activated-persulfate for the selective oxidation of PAH in groundwater remediation, J. Environ. Chem. Eng. 5 (2017) 6098-6106. https://doi.org/10.1016/j.jece.2017.11.038.

[173] R. Vargas, O. Núñez, The photocatalytic oxidation of dibenzothiophene (DBT), J. Mol. Catal. Chem. 294 (2008) 74-81. https://doi.org/10.1016/j.molcata.2008.08.001.

[174] J. Gómez, M.T. Alcántara, M. Pazos, M.A. Sanromán, Remediation of polluted soil by a two-stage treatment system: Desorption of phenanthrene in soil and electrochemical treatment to recover the extraction agent, J. Hazard. Mater. 173 (2010) 794-798. https://doi.org/10.1016/j.jhazmat.2009.08.103.

[175] J.M. Rosas, F. Vicente, A. Santos, A. Romero, Soil remediation using soil washing followed by Fenton oxidation, Chem. Eng. J. 220 (2013) 125-132. https://doi.org/10.1016/j.cej.2012.11.137. 
[176] X. Bai, Y. Wang, X. Zheng, K. Zhu, A. Long, X. Wu, H. Zhang, Remediation of phenanthrene contaminated soil by coupling soil washing with Tween 80 , oxidation using the UV/S2O82- process and recycling of the surfactant, Chem. Eng. J. (2019). https://doi.org/10.1016/j.cej.2019.03.116.

[177] C.M. Dominguez, A. Romero, A. Santos, Selective removal of chlorinated organic compounds from lindane wastes by combination of nonionic surfactant soil flushing and Fenton oxidation, Chem. Eng. J. 376 (2019) 120009. https://doi.org/10.1016/j.cej.2018.09.170.

[178] J. Radjenovic, D.L. Sedlak, Challenges and Opportunities for Electrochemical Processes as Next-Generation Technologies for the Treatment of Contaminated Water, Environ. Sci. Technol. 49 (2015) 11292-11302. https://doi.org/10.1021/acs.est.5b02414.

[179] E. Lacasa, S. Cotillas, C. Saez, J. Lobato, P. Cañizares, M.A. Rodrigo, Environmental applications of electrochemical technology. What is needed to enable full-scale applications?, Curr. Opin. Electrochem. 16 (2019) 149-156. https://doi.org/10.1016/j.coelec.2019.07.002.

[180] C.A. Martínez-Huitle, M.A. Rodrigo, I. Sirés, O. Scialdone, Single and Coupled Electrochemical Processes and Reactors for the Abatement of Organic Water Pollutants: A Critical Review, Chem. Rev. 115 (2015) 13362-13407. https://doi.org/10.1021/acs.chemrev.5b00361.

[181] L. Guo, Y. Jing, B.P. Chaplin, Development and Characterization of Ultrafiltration TiO2 Magnéli Phase Reactive Electrochemical Membranes, Environ. Sci. Technol. 50 (2016) 1428-1436. https://doi.org/10.1021/acs.est.5b04366.

[182] C. Trellu, B.P. Chaplin, C. Coetsier, R. Esmilaire, S. Cerneaux, C. Causserand, M. Cretin, Electro-oxidation of organic pollutants by reactive electrochemical membranes, Chemosphere. 208 (2018) 159-175. https://doi.org/10.1016/j.chemosphere.2018.05.026.

[183] C. Trellu, C. Coetsier, J.-C. Rouch, R. Esmilaire, M. Rivallin, M. Cretin, C. Causserand, Mineralization of organic pollutants by anodic oxidation using reactive electrochemical membrane synthesized from carbothermal reduction of TiO2, Water Res. 131 (2018) 310-319. https://doi.org/10.1016/j.watres.2017.12.070.

[184] E. Mousset, M. Puce, M.-N. Pons, Advanced Electro-Oxidation with Boron-Doped Diamond for Acetaminophen Removal from Real Wastewater in a Microfluidic Reactor: Kinetics and Mass-Transfer Studies, ChemElectroChem. 6 (2019) 2908-2916. https://doi.org/10.1002/celc.201900182.

[185] M. Panizza, P.A. Michaud, G. Cerisola, Ch. Comninellis, Anodic oxidation of 2naphthol at boron-doped diamond electrodes, J. Electroanal. Chem. 507 (2001) 206214. https://doi.org/10.1016/S0022-0728(01)00398-9.

[186] A.M. Zaky, B.P. Chaplin, Porous Substoichiometric TiO2 Anodes as Reactive Electrochemical Membranes for Water Treatment, Environ. Sci. Technol. 47 (2013) 6554-6563. https://doi.org/10.1021/es401287e.

[187] S.O. Ganiyu, N. Oturan, S. Raffy, M. Cretin, R. Esmilaire, E. van Hullebusch, G. Esposito, M.A. Oturan, Sub-stoichiometric titanium oxide (Ti4O7) as a suitable ceramic anode for electrooxidation of organic pollutants: A case study of kinetics, mineralization and toxicity assessment of amoxicillin, Water Res. 106 (2016) 171-182. 
https://doi.org/10.1016/j.watres.2016.09.056.

[188] S.O. Ganiyu, N. Oturan, S. Raffy, G. Esposito, E.D. van Hullebusch, M. Cretin, M.A. Oturan, Use of Sub-stoichiometric Titanium Oxide as a Ceramic Electrode in Anodic Oxidation and Electro-Fenton Degradation of the Beta-blocker Propranolol: Degradation Kinetics and Mineralization Pathway, Electrochimica Acta. 242 (2017) 344-354. https://doi.org/10.1016/j.electacta.2017.05.047.

[189] K. Benhabib, M.-O. Simonnot, M. Sardin, PAHs and Organic Matter Partitioning and Mass Transfer from Coal Tar Particles to Water, Environ. Sci. Technol. 40 (2006) 6038-6043. https://doi.org/10.1021/es0600431. 